\title{
Article \\ Quantifying the Use of Forest Ecosystem Services by Local Populations in Southeastern Cameroon
}

\author{
Simon Lhoest ${ }^{1, *}\left(\mathbb{D}\right.$, Cédric Vermeulen ${ }^{1}$, Adeline Fayolle ${ }^{1}\left(\mathbb{D}\right.$, Pierre Jamar ${ }^{1}$, Samuel Hette ${ }^{1}$, \\ Arielle Nkodo ${ }^{1}$, Kevin Maréchal ${ }^{1}$, Marc Dufrêne ${ }^{1}$ (D) and Patrick Meyfroidt ${ }^{2,3}$ (D) \\ 1 Gembloux Agro-Bio Tech, University of Liège, Passage des Déportés 2, 5030 Gembloux, Belgium; \\ cvermeulen@uliege.be (C.V.); adeline.fayolle@uliege.be (A.F.); ramja.pierre@gmail.com (P.J.); \\ samuelhette@gmail.com (S.H.); nkodoarielle@yahoo.fr (A.N.); K.Marechal@uliege.be (K.M.); \\ Marc.Dufrene@uliege.be (M.D.) \\ 2 Earth and Life Institute, UCLouvain, Place Pasteur 3, 1348 Louvain-la-Neuve, Belgium; \\ patrick.meyfroidt@uclouvain.be \\ 3 FRS-FNRS, Rue d'Egmont 5, 1000 Brussels, Belgium \\ * Correspondence: simlho@hotmail.com or simon.lhoest@uliege.be; Tel.: +32-499378920
}

Received: 9 February 2020; Accepted: 19 March 2020; Published: 23 March 2020

\begin{abstract}
In order to improve sustainability and design adequate management strategies in threatened tropical forests, integrated assessments of the use of ecosystem services are needed, combining biophysical, social, and economic approaches. In particular, no integrated ecosystem services (ES) assessment has been conducted in Central Africa, where rural communities deeply depend on forests in a high-poverty context. Here, we aimed to quantify the use of ES provided by tropical forests to local populations in the Dja area (Cameroon), identify its determinants and evaluate its sustainability. We conducted various interviews and field surveys with 133 households in three villages, focusing on three provisioning services (bushmeat, firewood, and timber), and five cultural services (cultural heritage, inspiration, spiritual experience, recreation, and education). Local populations consumed a mean of $56 \mathrm{~kg}$ of bushmeat/person/year (hunting zones covering on average $213 \mathrm{~km}^{2}$ ), $1.17 \mathrm{~m}^{3}$ of firewood/person/year (collection zones covering on average $4 \mathrm{~km}^{2}$ ), and $0.03 \mathrm{~m}^{3}$ of timber/person/year. Between $25 \%$ and $86 \%$ of respondents considered cultural services as important. The use of ES was mainly influenced by population size, deforestation rate, and forest allocations, whereas the influence of socio-demographic characteristics of households remained limited to slight differences between Baka and Bantu people. We conclude that the consumption of firewood and timber is sustainable, whereas high hunting pressure has resulted in severe defaunation in the area due to the large decline in the abundance and biomass of forest mammals hunted for bushmeat by local populations.
\end{abstract}

Keywords: Tropical forest; ecosystem services; use; provisioning services; cultural services; local populations

\section{Introduction}

The importance and extent of human impacts on the global environment have led to the recognition of the new Anthropocene era [1]. In the face of the largest environmental and biodiversity crisis, being recognized as the sixth extinction period [2], the importance of ecological systems to human societies has been raised, and the concept of ecosystem services (ES) emerged [3]. ES are defined as the contributions of ecosystems to human well-being [4]. Classically, ES are divided into provisioning, regulating, and cultural services [5], provisioning and cultural services being directly and daily used by people depending on the forests, especially in developing countries [6,7].

The Congo basin forests, which represent the second largest block of continuous tropical forests worldwide after the Amazon, provide important contributions to the rural livelihoods of more than 
60 million people [8]. With the exception of the surroundings of big cities [9] and roads [10], the Congo basin can be considered as a relatively preserved area with only little deforestation in comparison to the other tropical regions [11]. However, Central African forests are exposed to increasing human pressures, including population growth, climate change, overexploitation, and weak governance [9]. These pressures are susceptible to influence the capacity of forest ecosystems to provide ES to local populations [12], raising potential sustainability issues.

Provisioning services provided by tropical forests to local populations in Central Africa include wild food (bushmeat, fish, fruit, mushrooms, and caterpillars), water, raw materials (timber, fibers, and firewood), and traditional medicinal resources [13]. Among the different non-timber forest products (NTFP) collected by local populations (comprising 500 plant and 82 animal species in Cameroon [14]), bushmeat is of major importance. Bushmeat hunting is estimated between 4.6 and 4.9 million tons per year in Central Africa [15,16], and it provides a significant source of proteins in the diet [17]. In Cameroon, the annual turnover of the bushmeat sector is estimated at $€ 97$ million, contributing as much as the mining sector to the country's gross domestic product (GDP), without even considering self-consumption of bushmeat in rural areas which may account for over $€ 142$ million of gross annual economic benefit [18].

Firewood is also an important provisioning service throughout Central Africa, being the main wood resource and source of energy used by rural populations. The use of firewood and charcoal was mainly quantified in urban areas where the human pressure on natural resources is particularly strong [19]. Only few studies were conducted in rural forested areas [20], where firewood is directly gathered by local populations for self-consumption to satisfy their daily needs. In Cameroon, firewood constitutes the main source of energy for $83 \%$ of households [21]. The total consumption of firewood in rural areas of the country is estimated at four million tons per year, corresponding to an estimated total value of $€ 117.4$ million per year [20].

Timber is also provided by forests, and used by rural populations for house construction (framework, posts, and joineries) and furniture. The industrial timber sector also constitutes an important part of the national Cameroonian economy, producing 2.9 million of $\mathrm{m}^{3}$ year $^{-1}$ and contributing to $4 \%$ of the GDP: about $25 \%$ of logs are exported and about $62 \%$ of timber is transformed in the country [22]. The informal Cameroonian timber sector, through individual chainsaw milling, represents an estimated volume of $715,000 \mathrm{~m}^{3} \mathrm{year}^{-1}$, with an estimated annual turnover of $€ 93$ million [23]. Besides these figures, significant uncertainties still remain in the quantification of the local use of these provisioning services, the sustainability and the determinants of this use, especially for self-consumption and informal markets within rural areas.

Most ES assessments in Africa solely focused on provisioning services, and cultural services have been far less studied [24]. Participatory and mapping techniques are particularly useful for the assessment of cultural services, by linking social perceptions with environmental features, in any social-ecological system [25]. In a review of the most important ecosystem services in Africa [13], the cultural services mentioned included natural heritage sites, the use of natural areas for rituals and spiritual worship, the use of nature for education, and tourism and leisure sites (the latter being rarer in Central Africa). In the periphery of Yaoundé, the capital of Cameroon, several cultural services were assessed using participatory approaches, including cultural heritage, landscape aesthetics, social interaction, spiritual or religious experience, and intrinsic value [26]. In southeastern Cameroon, cultural heritage and identity, inspiration for culture and art, spiritual experience, opportunities for recreation and tourism, and education were all recognized important by rural populations [7]. The management of ecosystems can influence the provision of cultural services [26], on which human well-being directly depends $[27,28]$. As such, cultural services can be important motivators for managing, using, or protecting ecosystems [29]. In Central Africa, for instance, the Forest Stewardship Council (FSC) certification of production forests compels the logging companies to identify and respect the needs and cultural values of local communities inside forests areas allocated to production. 
In particular, the FSC-certified logging companies have to map and preserve the sacred sites and trees, and any important sites of cultural importance for local communities [30].

Using integrated approaches for ES assessment is claimed as urgent and essential for better informed decisions and actions about the use of natural resources and lands, improving sustainability as well as social and environmental justice [31]. Integrated approaches combine biophysical, social, and economic methods [31-33]. Biophysical approaches evaluate the properties of social-ecological systems with tangible measures [34,35]. Social approaches measure the values attributed by people to ES [36]. Economic approaches give monetary values to ES [37]. Each type of approach comprises numerous methods, such as measurements of ecological characteristics for biophysical approaches, individual interviews or focus groups for social approaches, and market-based valuation tools for economic approaches. Complementarily, ES mapping constitutes a visual technique to present ES values through a biophysical, social, or economic lens [38].

ES integrated assessments are lacking globally, and particularly in forest ecosystems where ES are far less studied than in other ecosystems such as agricultural areas [39]. Most ES assessments in forests have used economic approaches [39], whereas biophysical and social assessment methods need to be further investigated in these complex social-ecological systems. Only few studies conducted ES integrated assessment in tropical forests, for instance, in southern African woodlands with the identification of human-induced processes impacting ES supply [40] and the analysis of relationships between the supply of provisioning services and environmental income of local populations [41], or in Latin America where interdisciplinary approaches allowed providing concrete policy recommendations [42]. In particular, no integrated ES assessment has been conducted in Central Africa, where the livelihoods of rural populations deeply rely on forest ecosystems in a context of high-poverty.

In the Dja area (Cameroon), the perceptions of ES supplied by tropical forests to local populations have been quantified among three adjacent forest allocations largely represented in Central Africa: a protected area, a logging concession, and community forests [7]. The authors recommended further investigation on the use of some ES, in particular bushmeat, for which the supply did not meet the demand, and firewood and timber provision, as well as cultural services, for which the perceptions were the most variable and controversial, and this will need complementary social and biophysical assessment approaches. Despite their importance in rural livelihoods [43,44], other ES such as the gathering of some NTFP (raw materials, traditional medicine, edible insects, honey, etc.) and regulating services were not considered as a high priority for integrated ES assessment. Indeed, perceptions of the supply of these ES were highly homogenous among respondents and were then less controversial among different forest areas [7]. The identification of ES determinants is also crucial in order to design sustainable planning strategies, disentangling the roles of forest management $[16,27,45]$, local environment [46,47], and socio-demography [48,49].

Our main objective was to quantify the use of important ES provided by tropical forests to local populations in southeastern Cameroon. Specifically, we aimed to: (i) quantify and map the use of important provisioning and cultural ES by local populations; (ii) identify the influence of potential socio-demographic determinants of ES use at the household scale; (iii) identify the influence of potential determinants of ES use at the village scale, namely total population size, forest allocations, and deforestation rate; (iv) assess the sustainability of the consumption of provisioning services. Because of their importance for local populations [7], we focused on three provisioning services (bushmeat, firewood, timber) and five cultural services (cultural heritage and identity, inspiration for culture and art, spiritual experience, recreation, and education), by combining social and biophysical assessment approaches. In order to engage local communities for the political legitimacy of assessment findings [50], and to promote the social inclusiveness [26,51], we used participatory approaches to analyze the daily use of ES by local populations. The list of studied ES was based on the standard classification of The Economics of Ecosystems and Biodiversity-TEEB [52], considered as a follow-up of the Millennium Ecosystem Assessment for ES classification and valuation [5]. 


\section{Materials and Methods}

\subsection{Study Area}

This integrated ES study was conducted in southeastern Cameroon (East Province, latitude $2^{\circ} 49^{\prime}-3^{\circ} 44^{\prime} \mathrm{N}$, longitude $12^{\circ} 25^{\prime}-14^{\circ} 31^{\prime} \mathrm{E}$, mean altitude of 743 meters), located in the Guineo-Congolian Region where dense forests dominate [53,54]. Forests have been classified as moist for Central Africa [55] which corresponds to semi-deciduous forests. Mean annual temperature is $23.1^{\circ} \mathrm{C}$ and mean annual rainfall is $1640 \mathrm{~mm}$ distributed between two rainy seasons (August-November and March-June) [56].

The East Province is the most sparsely populated of the country, with an estimated population density of 7.7 inhabitants $/ \mathrm{km}^{2}$ in 2015 (www.citypopulation.de) and a sparse road network. The socio-economic surveys conducted as part of the management plans of the logging concessions in this area indicated a population density of 8 inhabitants $/ \mathrm{km}^{2}$ [57]. The production system of local populations is based on shifting cultivation, hunting, fishing, and gathering of forest products, in a landscape matrix where degraded secondary forests, crops, and fallow areas alternate along roads [58]. Local populations comprise Baka Pygmy and Bantu people, representing between 27,000 and 30,000 inhabitants in the study area [57]. The Baka people are the indigenous population of this area, being present before the Bantu people [59]. The Bantu people in this area correspond to the Makaa-Ndjem ethnolinguistic group (comprising Badjoué, Nzimé, and Ndjem) and the A80 Zone of the Guthrie classification of languages [60].

In Cameroon, the National Forest Estate (NFE) covers 37\% of the total country area [61] and comprises all forest areas allocated to particular uses. Three major forest allocations comprise $88 \%$ of the NFE and determine the management and use of forests: (i) protected areas $(42 \%$ of the NFE), comprising core areas and buffer zones; (ii) logging concessions (40\% of the NFE), comprising production, conservation, protection, and agroforestry zones; and (iii) community forests $(6 \%$ of the NFE). Protected areas are managed for the conservation of biodiversity and natural heritage. Logging concessions are dedicated to timber production through industrial logging and can be voluntarily certified for responsible management (such as FSC) or not. The FSC-certification engages the logging concession for the recognition of user rights of local populations, among other standards ensuring economic effectiveness, ecological integrity, and social equity [62]. The forest area allocated to FSC-certified logging concessions has, however, recently declined in Cameroon [63]. Community forests are small forest areas centered on villages and along roads, for which the management is decentralized at the scale of rural communities [58]. User rights differ among forest allocations. In the core area of protected areas and in the protection zones of logging concessions, agriculture, artisanal logging, hunting and gathering are prohibited. Agriculture and artisanal logging are also prohibited in the production and conservation zones of logging concessions, but gathering is allowed and hunting is regulated (non-protected species can be hunted with traditional selective techniques and for self-consumption only). In the buffer zones of protected areas, in the agroforestry zones of logging concessions, and in community forests, agriculture, artisanal logging and gathering are allowed, and hunting is restricted to traditional techniques for self-consumption of non-protected species.

We selected three villages surrounded by contrasted forest allocations (Figure 1, Appendix B). Malen I village is isolated inside a protected area (the Dja Biosphere Reserve) and is free of industrial logging. The Dja River can only be crossed by pirogue to penetrate inside the Reserve. Thus, no motor vehicle (apart from motorbike carried on a pirogue) can reach Malen I. The nearest town is Somalomo ( $\sim 5000$ inhabitants) located at $21 \mathrm{~km}$. Eschiambor and Mintoum villages are located within distinct community forests. Eschiambor village is located between an FSC-certified concession (PALLISCO Company) and a non-certified logging concession ("Societé Industrielle de Mbang"). The nearest city of Eschiambor is Lomié ( 19,000 inhabitants), located at $16 \mathrm{~km}$. Mintoum village is located between the protected area (Dja Biosphere Reserve) and the FSC-certified logging concession (PALLISCO Company), on a provincial road and at a distance of $7 \mathrm{~km}$ from Lomié. 

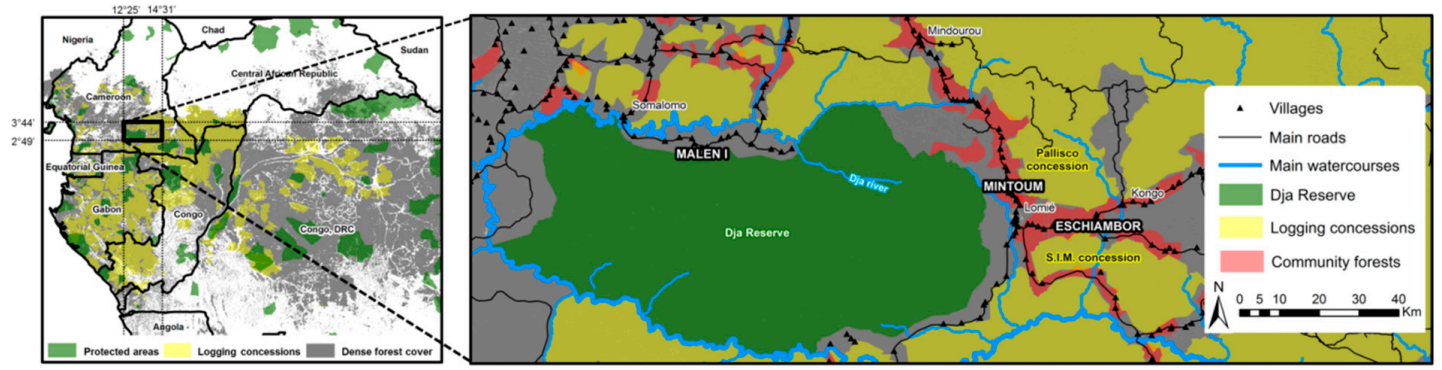

Figure 1. Study area located in the Dja area (southeastern Cameroon). The "Dense forest cover" (gray background) includes montane, submontane, lowland, and swamp forests of the land cover map of Africa [64]. We conducted our data collection for the quantification of ecosystem services use in three villages (which names are highlighted in black): Malen I (isolated in a protected area, the Dja Reserve in green), Eschiambor (located inside a community forest, in red, between a Forest Stewardship Council (FSC)-certified logging concession and a non-certified logging concession, both in yellow), and Mintoum (located inside a community forest, and between a protected area and a FSC-certified concession).

\subsection{Data Collection}

We conducted all interviews and quantitative field surveys between March and June 2018. We systematically explained the aim of our study to local populations and all data collection was conducted on a voluntary basis, with respondents giving their free, prior, and informed verbal consent for participation in the study. We conducted interviews in French for Bantu households and with a translator for Baka households. All questionnaires were tested with 10 households sampled randomly in one village and were adjusted when needed, before conducting the interviews and surveys. Investigators were trained to conduct the interviews and surveys in order to avoid any differences in data collection [65]. Investigators took notes and did not use a recorder. A sequence of social and biophysical methods (Figure 2) was used to characterize the sampled population (2.2.1.), quantify the use of bushmeat (2.2.2.), firewood (2.2.3.), timber (2.2.4.), and cultural services (2.2.5.), to analyze the determinants of ES use at the household and at the village scale (2.3.), and finally to evaluate the sustainability of the use of provisioning services (2.4.).

\subsubsection{Population Census and Sampling}

No up-to-date demographic data were available for the three studied villages. Therefore, in each village, we first conducted an exhaustive population census (Appendix B), using structured interviews with five directed questions ("a" in Figure 2): for all households, we recorded (i) the number of permanent residents (quantitative variable: defined as the number of household members spending the majority of their time in the village); (ii) the main source of income (four levels qualitative variable: salary jobs, agriculture, forest-related activities comprising hunting, fishing, gathering of NTFP and wood, or a mixed occupation); (iii) the ethnic group (two levels qualitative variable: Baka or Bantu); (iv) the origin (two levels qualitative variable: native from the village or not); (v) the maximum education level (four levels qualitative variable: out-of-school, primary school, secondary school, or graduate school), and we georeferenced the house.

Then, for the daily monitoring of ES use afterwards (bushmeat and firewood consumption), in each village, we sampled volunteer households (" $b$ " in Figure 2) stratified by the main source of income (salary/agriculture/forest/mixed) and by the ethnic group (Baka or Bantu) [44,66]. We sampled a total of 55 households (16 in Malen I, 19 in Eschiambor, and 20 in Mintoum, corresponding respectively to $100 \%, 49 \%$, and $26 \%$ of the total number of households in each village). 


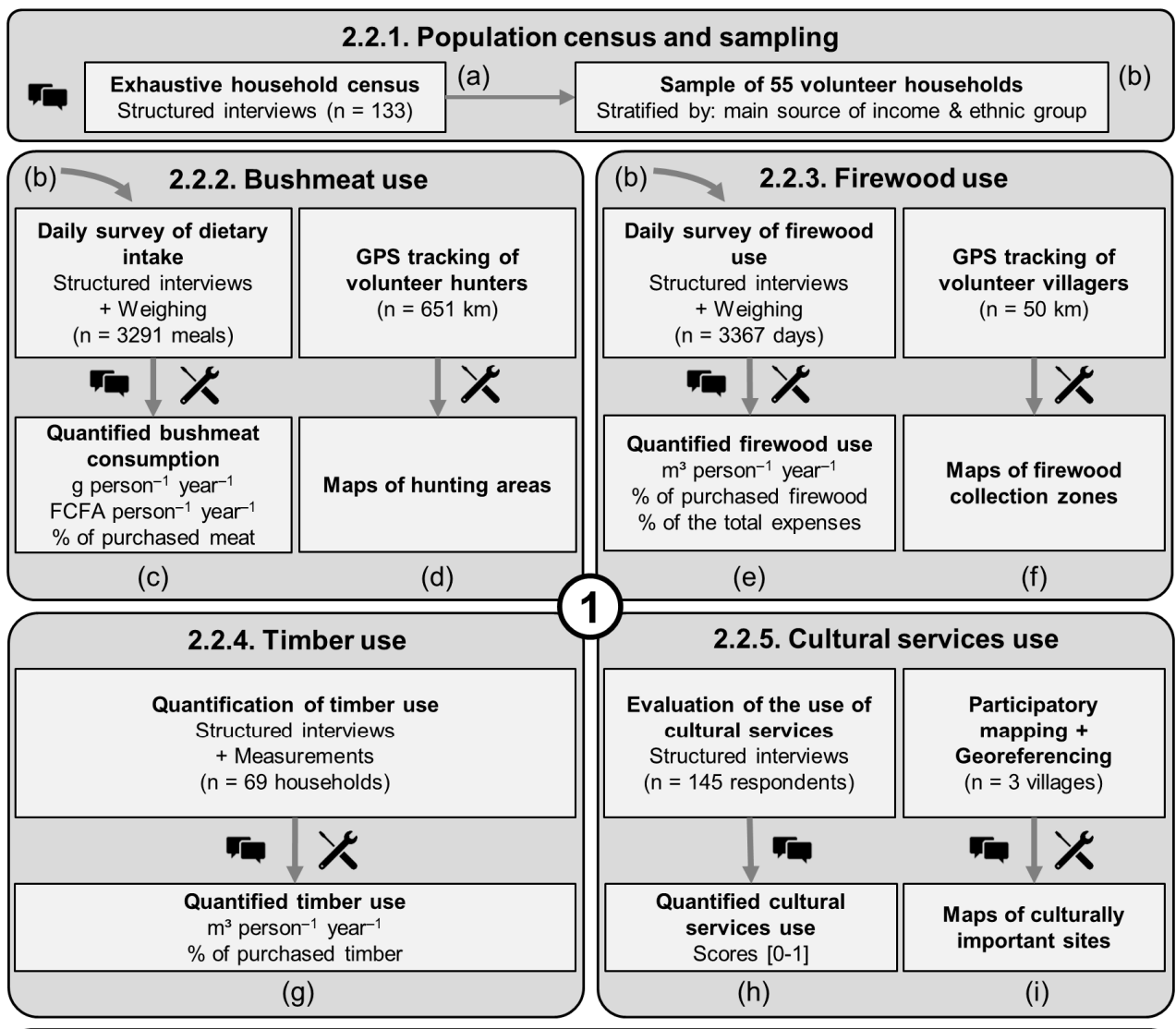

\begin{tabular}{|c|c|c|}
\hline \multicolumn{3}{|l|}{$(a, c, e, g, h)$} \\
\hline $\begin{array}{l}\quad \text { At the h } \\
\quad 40 \text { univari } \\
\text { Ecosystem services use } \\
\text { - Bushmeat } \\
\text { - Firewood } \\
\text { - Timber } \\
\text { - Cultural heritage } \\
\text { - Inspiration } \\
\text { - Spiritual experience } \\
\text { - Recreation } \\
\text { - Education }\end{array}$ & $\begin{array}{l}\text { usehold scale } \\
\text { te linear models: } \\
\text { socio-demographic variables } \\
\text { - Origin } \\
\text { - Ethnic group } \\
\text { - Main source of income } \\
\text { - Mean daily income } \\
\text { - Maximum level of education }\end{array}$ & $\begin{array}{l}\text { At the village scale } \\
\text { Interpretation of: } \\
\text { Extent of hunting areas, firewood collection zones, } \\
\text { culturally important sites } \\
\text { Limits of forest allocations } \\
\text { Tree cover and deforestation (Hansen et al., 2013) } \\
\text { Total population size }\end{array}$ \\
\hline
\end{tabular}

\begin{tabular}{|c|c|}
\hline 2.4. Sustainability of the & of provisioning services \\
\hline $\begin{array}{l}\text { Bushmeat } \\
\text { Consumption compared to the maximum production } \\
\text { of wild meat estimated at } 150-200 \mathrm{~kg} / \mathrm{km}^{2} / \mathrm{year} \\
\text { in tropical forests (Robinson \& Bennett, 2000) }\end{array}$ & $\begin{array}{l}\text { Firewood } \\
\text { Consumption compared to the biomass annual } \\
\text { increment estimated at } 5.46 \mathrm{Mg} \mathrm{ha}^{-1} \text { year-1 }^{-1} \\
\text { in Cameroon agro-forest areas (Djomo et al., 2011) }\end{array}$ \\
\hline
\end{tabular}

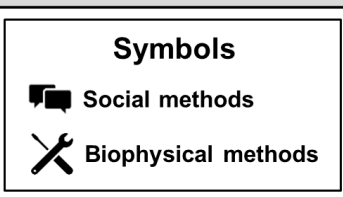

Figure 2. Social and biophysical methods used for the integrated assessment of ecosystem services use in three villages (Dja area, southeastern Cameroon), including data collection and analysis. Each subsection corresponds to a subtitle of the Material and Methods section. Circled numbers correspond to the four specific objectives of the study. Inputs and outputs of each method are symbolized by lower-case letters from "a" to "i". 


\subsubsection{Bushmeat Use}

Based on the daily monitoring of the 55 volunteer households conducted during three months by six trained investigators, we recorded the dietary intake of 3291 meals through structured interviews (five directed questions) and the weighing of bushmeat products $[67,68]$. For each meal, we recorded (i) if the household consumed animal proteins (two levels qualitative variable: yes/no), (ii) the type of proteins (three levels qualitative variable: bushmeat/fish/livestock), and (iii) the number of people eating (quantitative variable). If the meal contained bushmeat, we recorded (iv) if it had been hunted or purchased by the household (two levels qualitative variable). Specifically, in Eschiambor village, we weighed undressed meat (quantitative variable) with spring scales (maximum measurement of $10 \mathrm{~kg}$ ) when possible. We asked (v) the price if bushmeat had been purchased, and for collected bushmeat, we asked respondents to estimate the price of this quantity if they would have had to buy it (quantitative variable).

For the village of Eschiambor, we computed the mean daily mass of consumed bushmeat in $\mathrm{g}$ person $^{-1}$ day $^{-1}$ and the mean daily financial value of consumed bushmeat in FCFA person ${ }^{-1}$ day $^{-1}$ (means of the means of each household), and we extrapolated the mass consumption for a year. Over the whole dataset, and separating each village, we computed the proportion of meals for which bushmeat had been purchased (" $c$ " in Figure 2).

In order to map the hunting areas for the three villages [69], we accompanied volunteer hunters over $651 \mathrm{~km}$ with tracking on GPS (Global Positioning System) devices, as well as georeferencing all encountered traps, cartridges, hunting camps, and hunted animals. We generated minimum convex polygons computed on all corresponding GPS points and tracks to map the extent of the hunting zone in the neighborhood of each village (" $\mathrm{d}$ " in Figure 2). We considered a buffer zone of $5 \mathrm{~km}$ around each hunting camp as a proxy of the influence of hunters [70].

\subsubsection{Firewood Use}

Based on the aforementioned daily monitoring of the 55 volunteer households, we recorded 3367 days of firewood consumption [71]. Every evening, we weighed the quantity of firewood that the household estimated to be used until the next evening (quantitative variable), with spring scales (maximum measurement of $50 \mathrm{~kg}$ ) when possible. Through structured interviews (four directed questions), we recorded (i) if the firewood had been collected by the household or purchased (two levels qualitative variable), with (ii) the corresponding price (quantitative variable). For the analysis of the economic importance of firewood in the overall budget of households, we also recorded (iii) the daily total income (quantitative variable) and (iv) total expenses (quantitative variable) of each household every day. In order to compare the consumption of firewood and timber afterwards, we converted the measures of firewood mass into volume based on the measure of the "basic density" of 21 samples of firewood collected randomly in agricultural areas (average of $0.567 \mathrm{in} \mathrm{g} \mathrm{cm}^{-3}$ ), computed with their oven-dry weight divided by their wet volume [72].

Over the whole dataset, we computed the mean daily mass of firewood used in kg person ${ }^{-1}$ day $^{-1}$ (mean of the means of each household) and we converted it into volume, extrapolated for a whole year of consumption, in $\mathrm{m}^{3}$ person $^{-1}$ year $^{-1}$. We also computed the proportion of firewood mass which has been purchased, the proportion of purchased firewood in the total firewood consumption of buyer households, and the proportion of firewood purchase in their total expenses ("e" in Figure 2).

In order to map the zones of firewood collection [73], we also accompanied volunteer villagers over $50 \mathrm{~km}$ with tracking on GPS devices, as well as georeferencing collection sites. We generated minimum convex polygons computed on all corresponding GPS points and tracks to map the extent of the firewood collection zone in the neighborhood of each village (" $f$ " in Figure 2). We considered a buffer zone of $100 \mathrm{~m}$ around each collection point to consider the extent of agricultural fields where firewood was collected. 


\subsubsection{Timber Use}

We randomly sampled 69 households for the quantification of timber use: 12 in Malen I, 24 in Eschiambor, and 33 in Mintoum (corresponding respectively to $75 \%, 62 \%$, and $42 \%$ of the total number of households in each village). We only considered traditional house structure in the estimation of timber use, and either with straw roof or roof plate (Figure 3). For each household, we estimated the total volume of timber used, based on the wall surface. We first measured the wood volume used in $293 \mathrm{~m}^{2}$ of walls corresponding to nine houses, and considering wood poles as cylinders, this allowed computing a mean conversion factor from the wall surface to estimated timber volume used. We additionally measured the volume of boards used in the construction of roofs. Based on structured interviews (two directed questions and one open-ended question), we asked to the 69 considered households (i) if they had collected or purchased the timber used (two levels qualitative variable). We also asked them to estimate (ii) the durability of their house (quantitative variable, in years), and to mention (iii) the wood species used with local names (open answers) that we later translated in scientific names.

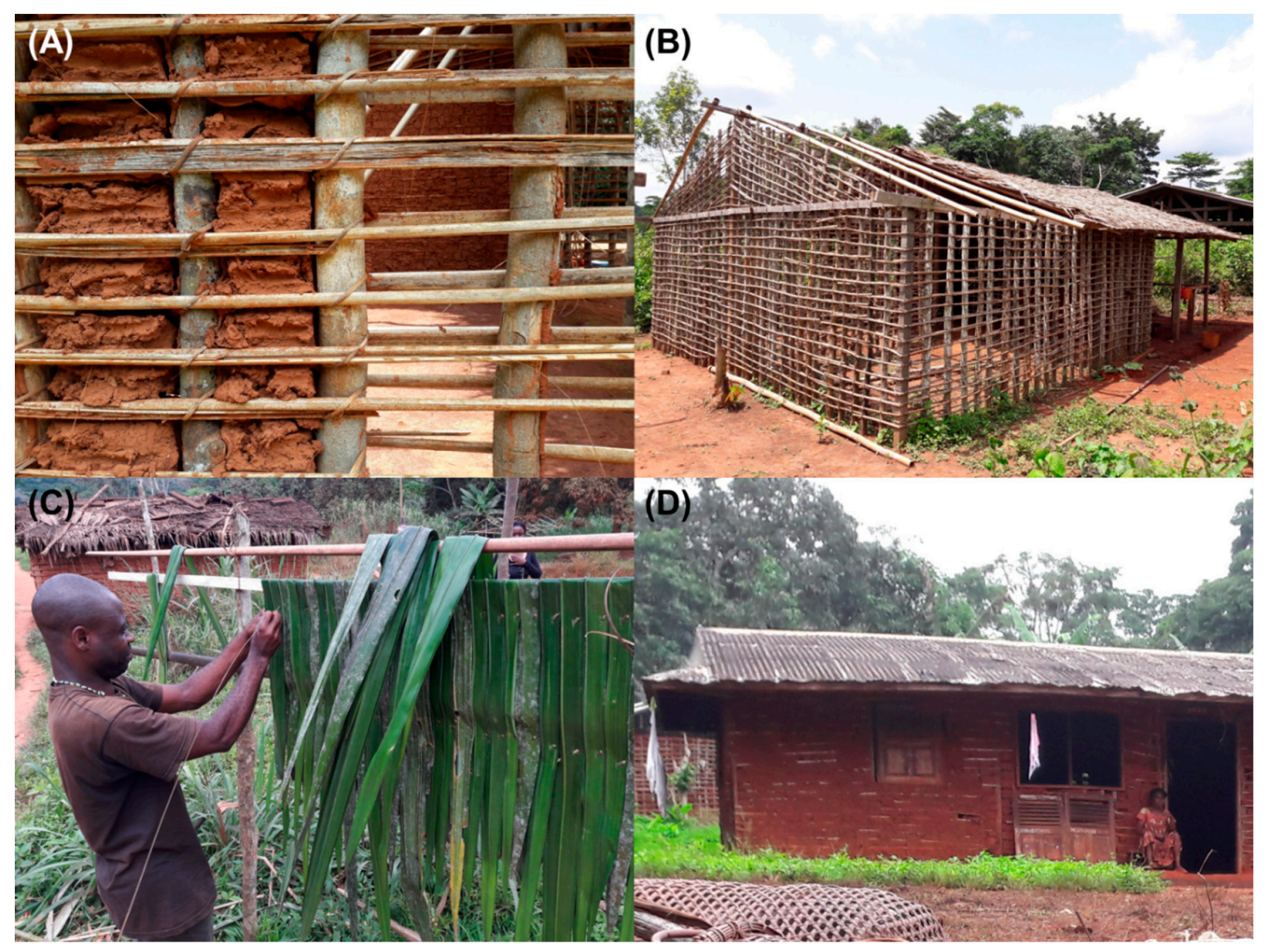

Figure 3. Traditional house type considered for the estimation of timber use in the integrated assessment of ecosystem services use in three villages (Dja area, southeastern Cameroon). (A,B) Traditional house structure. (C) Making of straw roof. (D) Roof plate.

Over the whole dataset, we computed the mean total volume of timber used to build a house and the proportion of timber volume which was purchased. Based on the mean estimated durability of houses and the number of permanent residents per household, we converted the total timber volume used in houses into $\mathrm{m}^{3}$ person $^{-1}$ year $^{-1}$ (" $\mathrm{g}$ " in Figure 2).

\subsubsection{Cultural Services Use}

For the evaluation of cultural services used by local populations [26], we used structured interviews to question 145 respondents belonging to 83 different households: 15 in Malen I, 24 in Eschiambor, and 
44 in Mintoum, corresponding respectively to $94 \%, 62 \%$, and $56 \%$ of the total number of households in each village. We used 14 open-ended questions relative to five different cultural services [7,52]: cultural heritage and identity, inspiration for culture and art, spiritual experience, recreation, and education (see the detailed list of questions in Appendix A). We coded answers in ordinal values: " 0 " value when the respondent totally disapproved, " 1 " value when the respondent totally approved, and " 0.5 " value in intermediate situations.

Over the whole dataset, and separating each village, we computed the mean value for all answers relative to a single ES, as a score attributed to the ES (mean of the means of each household; " $\mathrm{h}$ " in Figure 2).

In order to map all culturally important sites [30], we accompanied volunteer villagers to georeference relaxation sites, places of worship, sacred sites, and sacred trees. The list of all culturally important sites was previously compiled with villagers during a participatory mapping exercise [74] conducted in each village ("i $i$ " in Figure 2).

\subsection{Determinants of the Use of Ecosystem Services}

We tested five socio-demographic variables acquired at the scale of each household in the population census ("a" in Figure 2: origin, two levels qualitative variable; ethnic group, two levels qualitative variable; main source of income, four levels qualitative variable; mean daily income, quantitative variable; maximum level of education, four levels qualitative variable) as explanatory variables of the use of the eight ES in 40 univariate linear models (eight linear regressions for the only quantitative explanatory variable (mean daily income), and 32 analyses of variance for the four qualitative explanatory variables). We used as response variables: (i) the mean individual daily

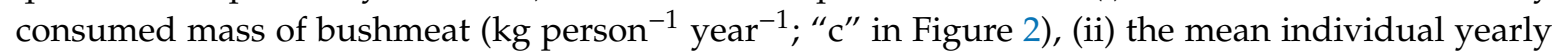

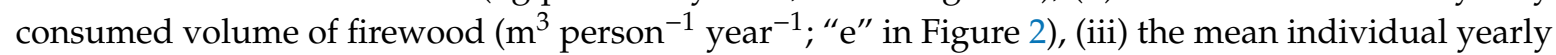
consumed volume of timber $\left(\mathrm{m}^{3}\right.$ person $^{-1}$ year $^{-1}$; " $\mathrm{g}$ " in Figure 2$)$, and (iv, v, vi, vii, viii) the mean scores attributed to the five cultural ES (from 0 to 1; " $h$ " in Figure 2). To identify the significant relationships, we computed the $F$-statistics of each linear model and the associated $P$-value (alpha $=0.05$ ).

In order to identify the influence of potential determinants of ES use at the village scale, we mapped the forest cover (in 2000) and the deforestation rates in the neighborhood of each village (over the 2000-2012 period) using geospatial data provided by Hansen et al. [75], as well as the limits of forest allocations, together with the extent of the hunting zones (" $\mathrm{d}$ " in Figure 2), firewood collection zones (" $\mathrm{f}$ " in Figure 2), and culturally important sites (" $\mathrm{i}$ " in Figure 2$)$, all related to the village population size ("a" in Figure 2).

\subsection{Sustainability of the Use of Provisioning Services}

In order to assess the sustainability of the use of provisioning services relatively to the extent of their collection zones, we estimated the consumption of bushmeat and firewood for comparison with general estimates of natural production in tropical forests.

For bushmeat, we estimated the total consumption in Eschiambor, extrapolated for a year (average consumption per capita in the village, " $c$ " in Figure 2, multiplied by the population size, "a" in Figure 2), and divided by the area of the observed zone of bushmeat hunting (" $d$ " in Figure 2). We then discussed the sustainability of bushmeat consumption, based on the maximum production of wild meat estimated in tropical forests [76]. Moreover, we confronted this result to the response of 24 hunters (split among the three villages) who were asked with a single directed question whether bushmeat abundance had evolved since the last decade (two levels qualitative variable: increase or decrease of animal abundance).

For each village, we computed the individual mean consumption of firewood in $\mathrm{Mg}_{\text {person }}{ }^{-1}$ year $^{-1}$ ("e" in Figure 2), multiplied by the number of inhabitants ("a" in Figure 2) and divided by the area of the firewood collection zone (" $\mathrm{f}$ " in Figure 2), itself multiplied by the mean proportion of tree cover (data from Hansen et al. [75]) within a distance of $2 \mathrm{~km}$ from the village for considering only the 
productive forest area where firewood is collected. We then discussed the sustainability of firewood use, based on biomass annual increment estimated in Cameroon agro-forest areas [77].

\section{Results}

\subsection{Quantification of the Use of Ecosystem Services}

Among provisioning services (Figure 4), local populations consumed a mean of $154 \mathrm{~g}$ of bushmeat person $^{-1}$ day $^{-1}$ in Eschiambor (standard deviation $=127 \mathrm{~g} \mathrm{person}^{-1}$ day $^{-1}$ ), corresponding to a daily budget of 88 FCFA person $^{-1}$ (standard deviation $=54$ FCFA person $^{-1}$ day $^{-1}$ ), and an extrapolation of 56 $\mathrm{kg}_{\text {person }}{ }^{-1}$ year $^{-1}$. Animal proteins were consumed in $39 \%$ of the 3291 recorded meals (over the three villages), themselves distributed among $58 \%$ of bushmeat products (divided between $57 \%$ purchased and $43 \%$ directly hunted by the households), 37\% of fish, and $5 \%$ of small livestock (comprising chicken, goat, and pork). On average, local populations used $1.8 \mathrm{~kg}$ of firewood person ${ }^{-1} \mathrm{day}^{-1}$ (standard deviation $=1.3 \mathrm{~kg}_{\text {person }}^{-1}$ day $^{-1}$ ). Only two households out of 55 purchased firewood. This represented $1 \%$ of total firewood consumption, but up to $34 \%$ of the total firewood consumption of buyer households, although only represented $1.4 \%$ of their total expenditures. Each household made use of $3.75 \mathrm{~m}^{3}$ of timber on average in the construction of its house (standard deviation $=2.17 \mathrm{~m}^{3}$ ), in which $21 \%$ of timber volume was purchased and $79 \%$ was directly extracted from the forest by the household. According to respondents, the mean estimated durability of houses was 35 years (standard deviation $=17$ years, average of 21 years for straw roof and 44 years for roof plate). The wood species mainly used and preferred in the construction of houses was sapelli (Entandrophragma utile (Dawe and Sprague) Sprague).

Among cultural services (Figure 4), the educational importance of the forest was recognized by $86 \%$ of respondents, who mentioned the hunting techniques and the NTFP gathering as important knowledge to be transferred to future generations. The forest was perceived by $73 \%$ of respondents as an important cultural heritage with vegetal and animal species to be conserved, as well as ancient villages and cemeteries. The forest also provided spiritual experiences to $56 \%$ of villagers, comprising sacred trees, sacred sites, places for rites and traditions. While only $27 \%$ of respondents declared to ramble in the forests for relaxation purpose without collecting any products, $62 \%$ of respondents reported to walk in the forest in order to escape from the problems of the village and $77 \%$ enjoyed their time spent in the forest, giving an overall score of $55 \%$ for the recreational service. Lastly, the inspiration of forest for culture and art was seen as significant by $25 \%$ of respondents, mentioning legends and stories told to children, as well as the inspiration of forests for craftsmanship. 


\section{Provisioning services}

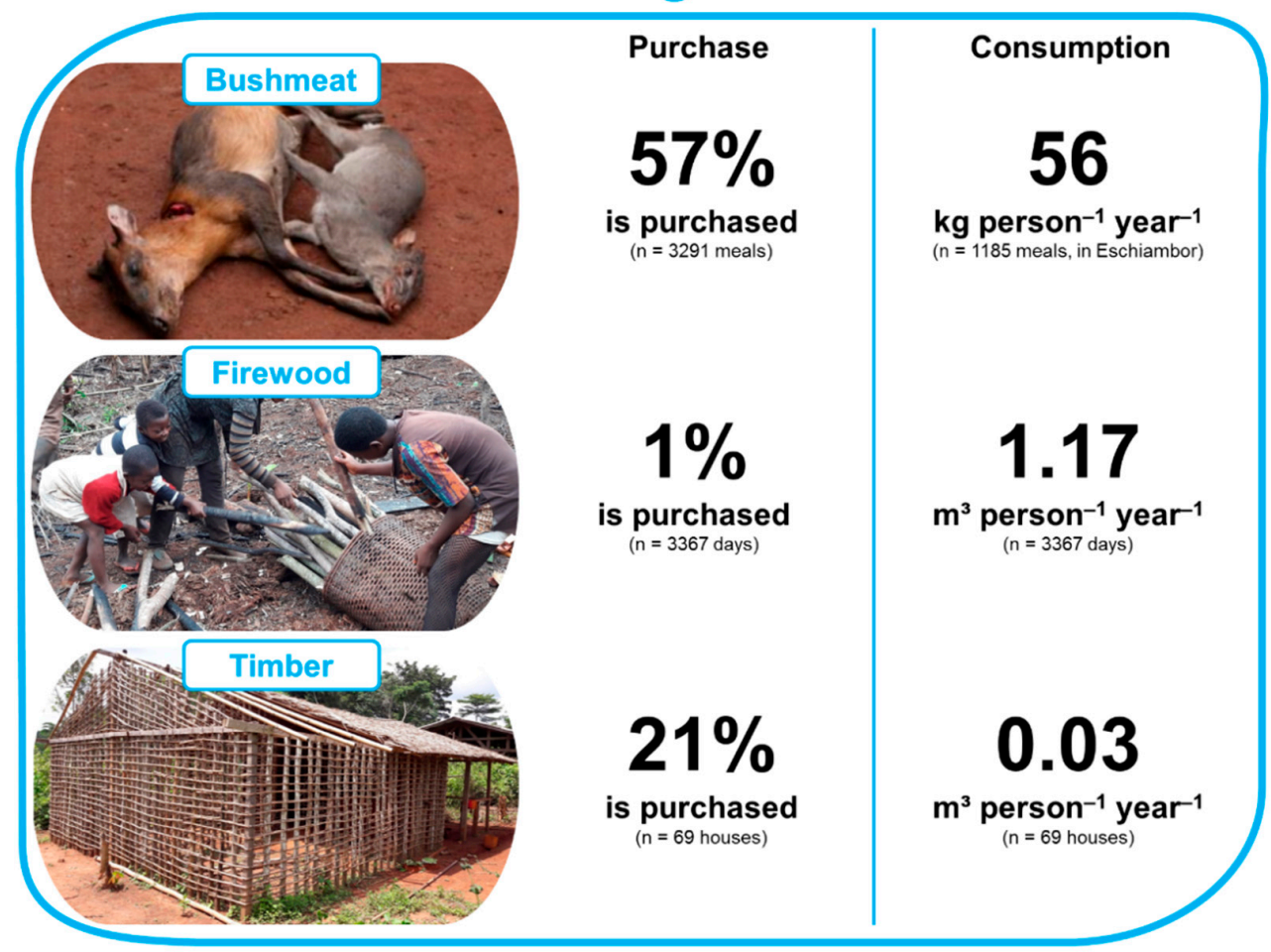

Cultural services

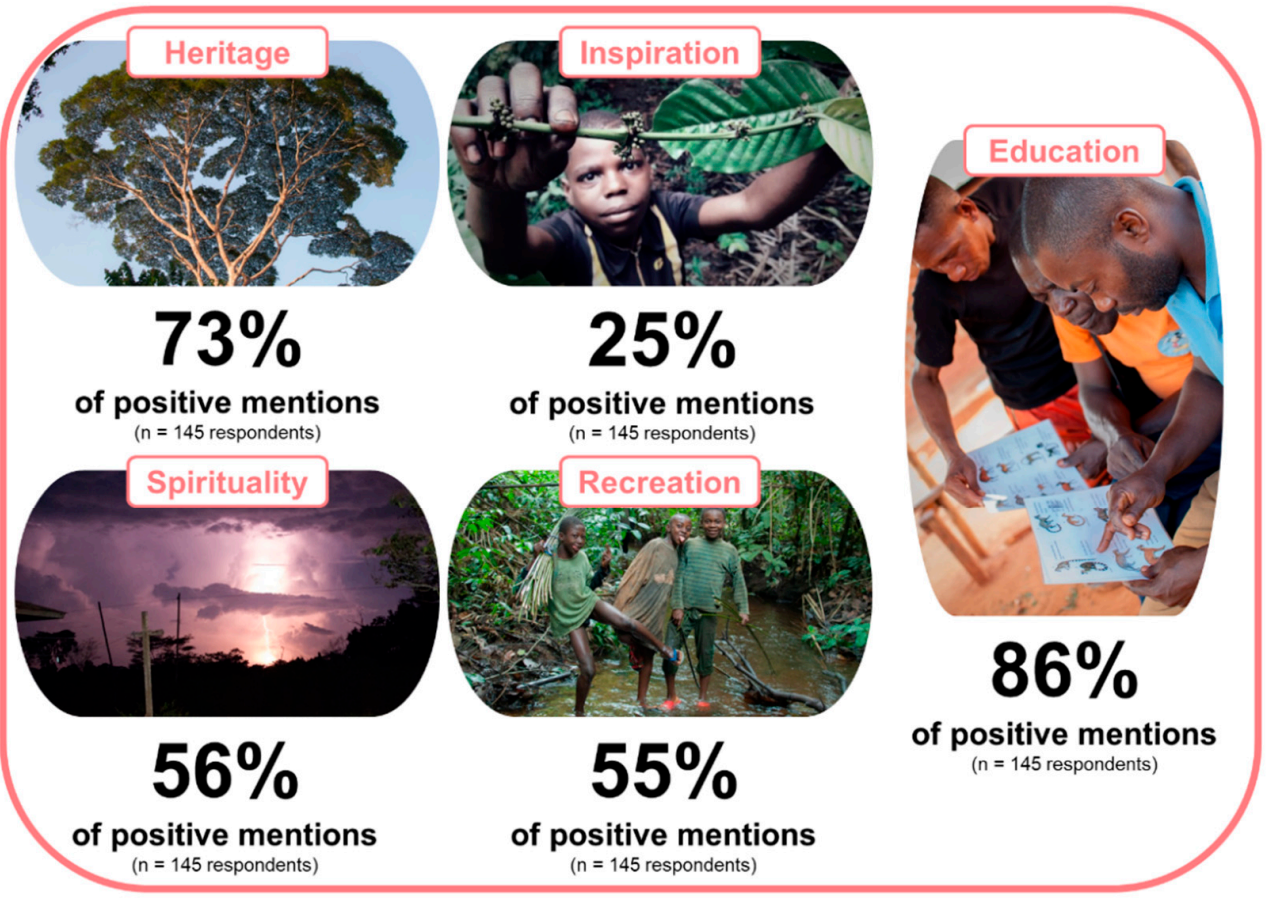

Figure 4. Quantification of key provisioning and cultural ecosystem services (ES) used by local populations in three villages of the Dja area (southeastern Cameroon). Average values presented here correspond to all households monitored and interviewed. Percentage values of purchase are computed as percentage of meals for bushmeat, and as percentage of the used volume for firewood and timber. The values given for cultural services correspond to the score between 0 and 1 attributed to each ES, which has been multiplied by 100 . 


\subsection{Determinants and Mapping of the Use of Ecosystem Services}

The three villages had very similar socio-demographic characteristics and household lifestyles, except a high proportion of Baka people in Mintoum ( $53 \%$ of households) and only Bantu people in the two other villages (Appendix B). In the 40 univariate linear models at the household scale, only the ethnic group was related to two cultural services (asterisks in Table 1$)$ : cultural heritage and identity ( $P$-value $=0.025)$, and spiritual experience $(P$-value $=0.044)$. The Baka people mentioned more frequently than Bantu people the importance of cultural heritage and spiritual experience. All conditions of application of linear models were verified and respected (simple random and independent samples, homoscedasticity, and normal distributions of residuals).

Table 1. $P$-values of the 40 univariate linear models between the use of ecosystem services (response variables) and socio-demographic variables at the household scale (explanatory variables) in three villages of the Dja area (southeastern Cameroon). For bushmeat consumption, we only used data acquired in the village of Eschiambor, with only Bantu people.

\begin{tabular}{ccccccc}
\hline Ecosystem Services & $\begin{array}{c}\text { Number of } \\
\text { Households }\end{array}$ & Origin & $\begin{array}{c}\text { Ethnic } \\
\text { Group }\end{array}$ & $\begin{array}{c}\text { Main Source of } \\
\text { Income }\end{array}$ & $\begin{array}{c}\text { Mean Daily } \\
\text { Income }\end{array}$ & $\begin{array}{c}\text { Maximum Level of } \\
\text { Education }\end{array}$ \\
\hline Bushmeat Consumption & 13 & 0.306 & - & 0.195 & 0.992 & 0.551 \\
Firewood Consumption & 47 & 0.145 & 0.125 & 0.735 & 0.232 & 0.054 \\
Timber Consumption & 32 & 0.499 & 0.387 & 0.334 & 0.463 & 0.304 \\
\hline Cultural Heritage and Identity & 43 & 0.838 & $0.025^{*}$ & 0.882 & 0.795 & 0.645 \\
Inspiration for Culture and Art & 43 & 0.236 & 0.115 & 0.127 & 0.096 & 0.584 \\
Spiritual Experience & 43 & 0.424 & $0.044 *$ & 0.585 & 0.583 & 0.076 \\
Recreation & 43 & 0.992 & 0.558 & 0.802 & 0.434 \\
Education & 43 & 0.873 & 0.156 & 0.579 & 0.856 \\
\hline
\end{tabular}

Note: Asterisks $\left({ }^{*}\right)$ refer to significant $P$-values $(<0.05)$.

We used a total of 1358 georeferenced points of hunting activities (1182 traps, 71 cartridges, 23 hunting camps, and 82 hunted animals), 117 georeferenced collection sites of firewood, and 26 georeferenced sites of cultural importance for the mapping of the ES use. When considering the use of ES at the village scale, two clear results appeared (Figure 5). First, the sparsely populated and isolated village Malen I showed a hunting zone seven times smaller than the two other villages. Meanwhile, people in Malen I consumed less frequently bushmeat (15\% of all meals) than in the two other villages (27\% of all meals in Eschiambor, and 22\% of all meals in Mintoum), and consumed more frequently fish (28\% of all meals, against $6 \%$ of all meals in Eschiambor and $13 \%$ of all meals in Mintoum). Fish in Malen I is caught in the Dja river situated at only two kilometers from the village. Bushmeat in Malen I was also more frequently hunted directly by the consuming households ( $53 \%$ of meals) than purchased, contrary to the two other villages ( $40 \%$ of meals from direct hunting in Eschiambor, and $24 \%$ in Mintoum). Second, the isolated village of Malen I showed much lower mentions of the cultural importance of forests for local populations than in the two other villages. In particular, only $33 \%$ of respondents in Malen I mentioned the spiritual experience attributed to the forest, compared to $55 \%$ in Eschiambor and 72\% in Mintoum. Only two cultural sites were mentioned by the inhabitants of Malen I: a sacred tree and an inselberg recognized for its heritage value. In Eschiambor, five culturally important sites were identified: a sacred site, an ancient village where some villagers still maintain ancestral rituals, a cascade considered as a relaxation site, and two sacred trees used for traditional medicine. In Mintoum, the only village where we interviewed Baka people (who constitute $53 \%$ of respondents), 19 cultural sites were identified and were mostly linked to the Baka people: four sacred sites, two ancient villages, a tomb, a cascade considered as a relaxation site, and 11 sacred trees either used for traditional medicine or mourning ceremonies. 


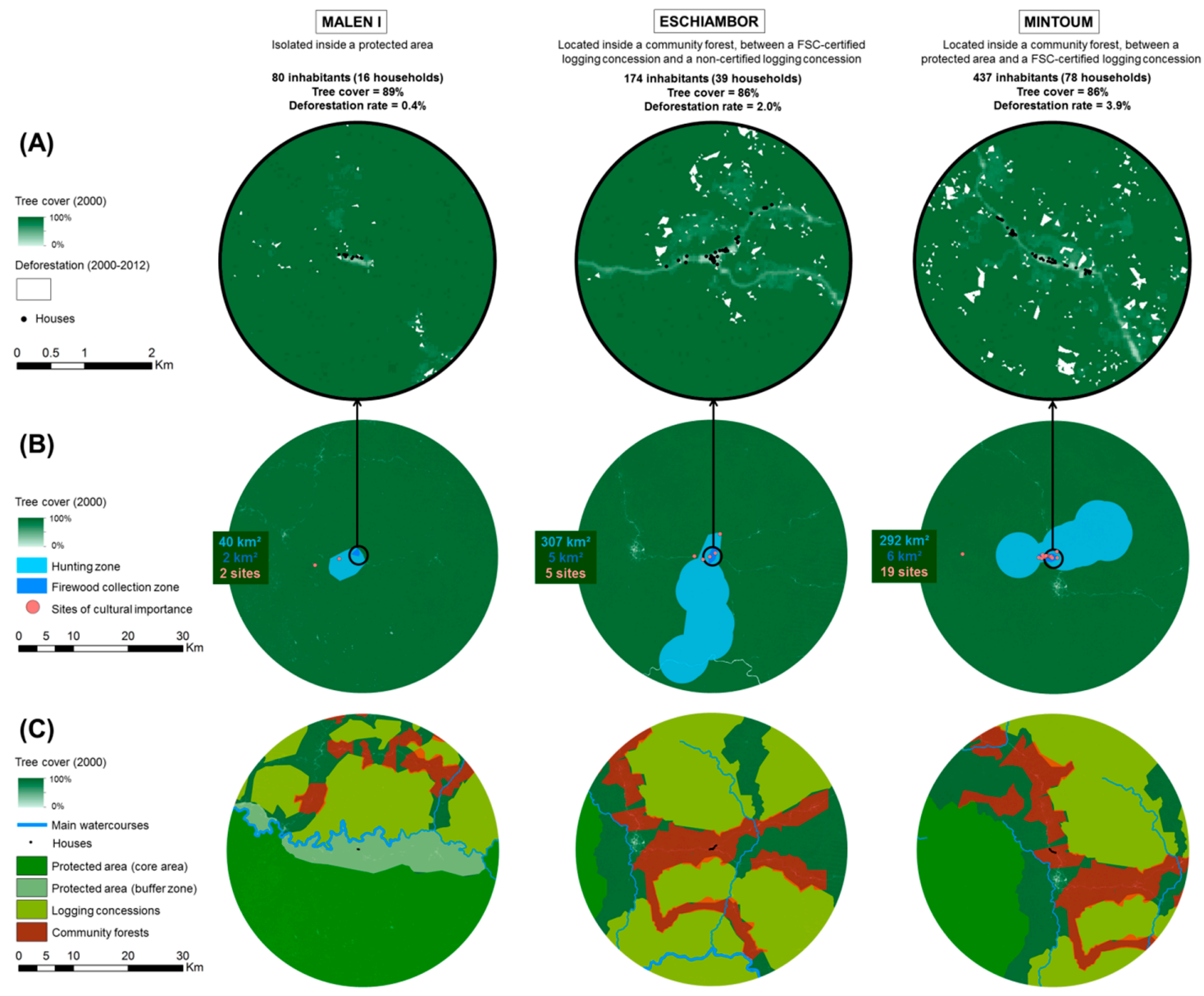

Figure 5. Characteristics of the three studied villages in the Dja area (southeastern Cameroon) in which we conducted an integrated assessment of ecosystem services use. (A) Tree cover in 2000, tree cover loss between 2000 and 2012 [75], and location of housings in the settlement area of each village. (B) Spatial extent of bushmeat hunting and firewood collection zones, generated by minimum convex polygons using all GPS (Global Positioning System) points and tracks recorded during the study. Sites of cultural importance are mapped as points. (C) Forest allocations and main watercourses in the surroundings of villages.

\subsection{Estimated Consumption of Provisioning Services for Discussing Sustainability}

The total consumption of bushmeat estimated in Eschiambor was $32 \mathrm{~kg} / \mathrm{km}^{2} /$ year. Moreover, all of the 24 hunters questioned about the evolution of bushmeat abundance noticed a decrease since the last decade. The estimation of total firewood mass used annually in each village was: $0.38 \mathrm{Mg} \mathrm{ha}^{-1} \mathrm{year}^{-1}$ in Malen I, $0.20 \mathrm{Mg} \mathrm{ha}^{-1}$ year $^{-1}$ in Eschiambor, and $0.69 \mathrm{Mg} \mathrm{ha}^{-1}$ year ${ }^{-1}$ in Mintoum.

\section{Discussion}

Here, we conducted the first integrated assessment of ES use by local populations in southeastern Cameroon tropical forests, using both social and biophysical approaches. We identified a high influence of village characteristics (population size, deforestation rate, surrounding forest allocations) on the ES use (Figure 5), whereas socio-demographic characteristics of households were much less informative (Table 1), as shown for the perceptions of ES supply [7]. Among the three studied villages, the population size, the deforestation rate, and the extent of the zones of ES use showed positive correlation (Figure 5), and indeed deforestation influences and decreases the ES supply and use [44]. 


\subsection{Bushmeat Consumption}

The area of hunting zones around villages varies between $40 \mathrm{~km}^{2}$ (Malen I) and $307 \mathrm{~km}^{2}$ (Eschiambor). As a comparison, the hunting zones of other villages varied between 170 and $518 \mathrm{~km}^{2}$ in the same study area, and between 25 and $600 \mathrm{~km}^{2}$ in a larger dataset including villages in Cameroon, Congo, and Central African Republic, the population size being a major determinant of the hunting zone area [78]. In order to compare the extent of forest use among different villages, the use of a spatial occupancy index is suggested [79], defined as the ratio between the area used (here, for bushmeat hunting) and the number of permanent households living in the village. In our study area, the villages show the following indices: Malen $2.5 \mathrm{~km}^{2} /$ household, Eschiambor $7.9 \mathrm{~km}^{2} /$ household, and Mintoum $3.7 \mathrm{~km}^{2} /$ household. These values are all higher than the mean spatial occupancy index of $2.0 \mathrm{~km}^{2} /$ household previously reported in this area [79]. This may show the relative defaunation around the studied villages, obliging hunters to cover larger areas to get enough animal proteins. The extent of hunting zones largely covers forest allocations where hunting is forbidden, such as the protected area and logging concessions (also observed previously in the same zone [78]), showing the ineffectiveness of official regulations [80]. However, anti-poaching operations can have a dissuasive effect on the preferred directions of hunters (Figure 5) in the protected area (preference of Mintoum's hunters for the FSC-certified logging concession) and in the FSC-certified logging concession (preference of Eschiambor's hunters for the non-certified logging concession).

The high frequencies of bushmeat consumption reported (34\% to $76 \%$ of meals with proteins, corresponding to $15 \%$ to $27 \%$ of all meals) confirmed the high dependence of rural populations on forest ecosystems to meet their dietary needs $[16,76]$. These results are comparable with another dietary monitoring conducted in the same area, showing that $12 \%$ of $21 \%$ of all meals contained bushmeat [81]. In Malen I, the majority of consumed bushmeat was directly hunted by the consuming households (53\%), whereas most bushmeat was purchased in Mintoum (74\%), which is situated in the most deforested part of our study area. The unit price of bushmeat increases with deforestation [82], inducing a negative feedback loop towards even more hunting, and further in the forest, due to the context of high poverty.

We found that the inhabitants of Eschiambor consumed a mean of $154 \mathrm{~g}$ of bushmeat person $^{-1}$ day $^{-1}$, which is comparable to other measures in the Dja area, going from 75 to $164 \mathrm{~g}$ person $^{-1}$ day $^{-1}[78,83]$. It is 3.6 times more than the daily dietary recommendations of $43 \mathrm{~g}$ of meat from the EAT-Lancet report [84]. It is 3.8 times higher than the average consumption of bushmeat from forest sources in Cameroon, which is reportedly $41 \mathrm{~g}_{\text {person }}{ }^{-1}$ day $^{-1}$ considering FAO statistics for the country [85], knowing that not all populations are directly depending on forest resources. It is under the average meat consumption in industrialized countries, which is $241 \mathrm{~g} \mathrm{person}^{-1}$ day $^{-1}$ [86].

Bushmeat consumption reported to the area of the hunting zone in Eschiambor $\left(32 \mathrm{~kg} / \mathrm{km}^{2} /\right.$ year $)$ was lower than the measures of 93 to $173 \mathrm{~kg} / \mathrm{km}^{2} /$ year reported in villages of the same zone in 2001 [78]. It is also below the sustainability standard of the maximum production of wild meat roughly estimated between 150 and $200 \mathrm{~kg} / \mathrm{km}^{2} /$ year in tropical forests [76]. Even if bushmeat consumption in Eschiambor could then seem to be sustainable, inventories of mammal populations have shown that only small animals remain in these areas close to villages and roads due to past hunting pressure [87]. Indeed, a high and growing hunting pressure induces a decline in the biomass of forest vertebrates, with large-bodied preferred game species declining rapidly [88,89]. Moreover, the human density of one person per $\mathrm{km}^{2}$ suggested as the maximum density in order to maintain sustainable bushmeat consumption [76] is eight times less than the population density in our study area. The lack of accurate biological data for each hunted species (such as the age at first reproduction, fecundity, and maximum longevity) does not allow us to precisely quantify the sustainability of bushmeat hunting in the study area [90]. However, it has already been suggested that the hunting practices are not sustainable in Cameroon [91] and in the Dja region in particular [92]. In a sustainable bushmeat exploitation scenario, bushmeat could only contribute to $10 \%-18 \%$ of the whole protein supply across Cameroon and other sources of protein would be needed from the agricultural sector [91]. Many forest areas in Central 
Africa are already considered as almost empty of wildlife [45], and 55\% of species are being hunted unsustainably in Central Africa according to the IUCN Red List [93].

\subsection{Firewood and Timber Consumption}

Whereas most studies on firewood consumption were conducted in urban areas [20], the use of firewood in this rural and forested area was $1.8 \mathrm{~kg} \mathrm{person}^{-1}$ day $^{-1}$. This is $20 \%$ higher than the average consumption throughout Africa (1.5 kg person ${ }^{-1}$ day $^{-1}$ [94]), and comparable to the average consumption in Cameroon (1.9 $\mathrm{kg}$ person ${ }^{-1}$ year $^{-1}$, according to FAO-ForeStat). This is three times the daily consumption of $0.6 \mathrm{~kg}_{\text {person }}{ }^{-1}$ day $^{-1}$ measured in the dry forest area in the Far North Region of Cameroon where firewood is overexploited [95]. The consumption of charcoal remains negligible in Cameroon rural areas [20].

There are few studies about the use of firewood in forested rural areas in Central Africa and Cameroon, but there are even less studies about the use of timber for the construction of houses. Our results showed an average use of $3.75 \mathrm{~m}^{3}$ of timber per household in the construction of its house, and general rough estimates across Africa give an average of 0.5 to $6 \mathrm{~m}^{3}$ per household [94]. When converting the total volume to the volume used per person and per year (based on the estimated durability of houses), we obtained a consumption of $0.03 \mathrm{~m}^{3}$ person $^{-1}$ year ${ }^{-1}$, whereas data from the Far North Province in Cameroon showed a volume of $0.01 \mathrm{~m}^{3}$ person ${ }^{-1}$ year $^{-1}$ in urban areas and $0.05 \mathrm{~m}^{3}$ person ${ }^{-1}$ year $^{-1}$ in rural areas [96]. With more income being allocated to housing improvements, local populations mentioned that they would seek to use mud bricks and roof plate.

Whereas local populations did not show any preferences about wood species for firewood collection, some species were preferred over others for house construction, in a desire for better resistance to humidity and xylophagous insects. Sapelli was the most used wood species in timber construction: the FSC-certified logging concession logged $0.07 \mathrm{~m}^{3} \mathrm{ha}^{-1}$ year ${ }^{-1}$ of sapelli in 2013, whereas the living stock of that species was about $3.81 \mathrm{~m}^{3} \mathrm{ha}^{-1}$ in the study area [57]. In comparison, based on the maximum area of a community forest (5000 ha) and the population size of the most populated village in our study area (Mintoum, 437 inhabitants), the total volume of timber used for house construction could reach $0.003 \mathrm{~m}^{3} \mathrm{ha}^{-1}$ year $^{-1}$ for all species combined, which is 23 times less than the volume logged in the logging concession only for the sapelli species. In volume, the consumption of firewood was 39 times higher than the consumption of timber for the construction of houses in our study area. We then considered that the timber extraction for local use in the construction of houses has only a limited impact on forest ecosystems but that the sustainability of firewood collection can be questioned. We estimated the total firewood mass used annually in each village ( $0.38 \mathrm{Mg} \mathrm{ha}^{-1}$ year $^{-1}$ in Malen I, $0.20 \mathrm{Mg} \mathrm{ha}^{-1}$ year $^{-1}$ in Eschiambor, and $0.69 \mathrm{Mg} \mathrm{ha}^{-1}$ year ${ }^{-1}$ in Mintoum). Based on a biomass annual increment of $5.46 \mathrm{Mg} \mathrm{ha}^{-1}$ year $^{-1}$ estimated in Cameroon agro-forest areas [77], the consumption of local populations would constitute approximately up to $13 \%$ of the natural growth of the wood resource (7\% in Malen I, $4 \%$ in Eschiambor, and 13\% in Mintoum). This only constitutes a rough estimate of the sustainability of firewood use but it gives an informative order of magnitude. Of course, firewood is not the only wood resource extracted from these forests, but it shows than firewood collection is not a major threat on forest ecosystems in this area. Moreover, firewood is a by-product of shifting agriculture and is only collected as dead wood in agricultural areas [97]. Directly linked to the total population size, it is the extent of agricultural zones that impacts the forest cover and potentially leads to net deforestation [98].

\subsection{Cultural Services Use}

Among the important cultural services that we identified here, cultural heritage, spiritual experience and inspiration were also frequently perceived as abundant in the same area [7]. The educational value of forest ecosystems for children in the acquisition of local knowledge has also been highlighted in this zone [99]. The differences in cultural services identified among the three villages could be explained as follows. First, the rare mentions and use of cultural services in 
Malen I are probably due to the fact that this village only exists since the foundation of the protected area in 1950. Local populations may have developed only few cultural connections with forest ecosystems. The populations of the two other villages migrated from nearby locations in the current logging concessions during the recent decades, and local people consider ancient villages as places of worship [58]. Second, the higher proportion of Baka people in Mintoum may explain the high cultural importance of forests for local populations in this village. Baka people systematically evaluated cultural services as more important than Bantu people did, and they identified many sites of cultural importance (Figure 5). The only Baka respondents were interviewed in Mintoum (53\% of households interviewed about cultural services in this village). Despite a recent trend of sedentarization and involvement in agricultural activities instead of their ancestral hunter-gatherer nomadic lifestyle [100], Baka people still maintain many rituals and traditions linked to the forest $[101,102]$. The different cultural preferences among villages may also be related with the different ethnolinguistic groups of Bantu people: mainly Badjoué in Malen I, and mainly Nzimé in Eschiambor and Mintoum [103].

Altogether, our results underline what may be referred as to the culturality of ES [104]. Despite their importance for ES assessment [105], cultural services have been far less studied than provisioning services. This is likely due to the lack of adequate assessment framework and the complexity to address them with traditional quantitative approaches [29,106,107]. Going further than the classic Western concept of cultural services (such as recreation), the recent works on the concept of Nature's Contributions to People (developed in the frame of the Intergovernmental Platform on Biodiversity and Ecosystem Services-IPBES) starts from acknowledging the importance of non-instrumental values and the related interplay between emotional, social, and cultural factor [108]. It raises the important roles of culture, indigenous, and local knowledge in understanding the links between people and nature [106]. This concept suggests working both at a general level and at a context-specific level, the latter giving room for multiple ways of understanding and categorizing relationships between people and nature in the reach of sustainability.

\section{Conclusions}

Our study quantified and mapped the use of important ES provided by tropical forests to local populations in southeastern Cameroon. We confirmed that population size, deforestation rate, and forest allocations may be determinants of the use of forest ES, whereas socio-demographic characteristics of households have a limited influence. Forest-related cultural services were partly shaped by ethnicity, with Baka people attributing much more cultural importance to forest ecosystems than Bantu people. Among provisioning services, we identified the sustainable use of firewood and timber by local populations, but we showed that past high hunting pressure limited the availability of bushmeat. Methods and results of ES assessment as ours must be implemented in concrete management strategies at local and regional scales in order to achieve sustainability, by engaging local communities into the assessment process for the social inclusiveness [26,51] and the political legitimacy of assessment findings [50].

Author Contributions: Conceptualization, S.L., C.V., A.F., M.D. and P.M.; Data curation, S.L.t, P.J., S.H. and A.N.; Formal analysis, S.L., P.J., S.H. and A.N.; Funding acquisition, S.L., C.V., A.F., P.J., S.H., A.N. and M.D.; Investigation, S.L., P.J., S.H. and A.N.; Methodology, S.L., C.V., P.J., S.H. and A.N.; Project administration, S.L.; Resources, S.L., P.J., S.H. and A.N.; Software, S.L., P.J., S.H. and A.N.; Supervision, S.L., C.V., A.F., M.D. and P.M.; Validation, C.V., A.F. and P.M.; Visualization, S.L.; Writing - original draft, S.L., A.F. and P.M.; Writing - review \& editing, S.L., C.V., A.F., A.N., K.M., M.D. and P.M. All authors have read and agreed to the published version of the manuscript.

Funding: The work of Simon Lhoest was supported by FRIA (F.R.S.-FNRS, grant number 5125916F). Funding support was also provided by the FORECAST project funded by Agropolis Fondation, University of Liège (mobility grant for the student internship of Samuel Hette, scholarship for the Master and mobility grant of Arielle Nkodo), and "Académie de Recherche et d'Enseignement Supérieur de la Fédération Wallonie-Bruxelles" for the mobility of Pierre Jamar.

Acknowledgments: We thank Nature+ asbl (Charles Bracke), the Pallisco Company (Paul Lagoute), the Cameroon Forest Administration, the Ministry of Forests and Wildlife of Cameroon and particularly the Conservation Service 
of the Dja Biosphere Reserve (Head of Somalomo Antenna), the Head of Forest Administration in Lomié (Mahamat Chetima), the management committees of the community forests of Avilso and Eschiambor, and Bonaventure Sonké for their logistic support. We thank all the villagers who welcomed us and participated in our interviews and field surveys. Thanks to our seven investigators and our Baka translator. Acknowledgements are also due to Gauthier Ligot, Jacques Hébert, Ludovic Andres, Thomas Dogot, Pauline Gillet, Kasso Daïnou, Jean-Louis Doucet, and Yves Brostaux for providing advice on field protocols and data analyses. We sincerely thank four anonymous reviewers for their constructive suggestions that helped to improve the manuscript.

Conflicts of Interest: The authors declare no conflict of interest. The funders had no role in the design of the study; in the collection, analyses, or interpretation of data; in the writing of the manuscript, or in the decision to publish the results.

\section{Appendix A}

Table A1. List of 14 open-ended questions asked to 145 respondents for the evaluation of five cultural services.

\begin{tabular}{cc}
\hline Open-Ended Questions \\
\hline Inspiration for Culture and Art & $\begin{array}{c}\text { Does the forest have heritage, cultural, or symbolic value for you? } \\
\text { Are there animal or vegetal species to conserve for the future? } \\
\text { Do you know any cemeteries or ancient villages in the forest? }\end{array}$ \\
\hline Spiritual Experience & $\begin{array}{c}\text { Are there legends and stories about the forest? } \\
\text { Are the craftsmen inspired by the forest? }\end{array}$ \\
Recreation & $\begin{array}{c}\text { Do you practice any forest-related rituals or traditions? } \\
\text { Are there sacred trees in the forest? } \\
\text { Are there sacred sites in the forest? }\end{array}$ \\
Have sacred sites retained the same importance than before? & Is it pleasant to go into the forest? \\
Education & $\begin{array}{c}\text { Do you ramble in the forest to relax without collecting anything? } \\
\text { Do you sometimes go into the forest to escape the problems of the } \\
\text { village? }\end{array}$ \\
& $\begin{array}{c}\text { Is it the forest important for children's education? } \\
\text { pass on? }\end{array}$ \\
\hline
\end{tabular}

\section{Appendix B}

Table A2. Socio-demographic characteristics of the $n$ studied households in each village.

\begin{tabular}{|c|c|c|c|c|}
\hline & & Malen I $(n=16)$ & Eschiambor $(n=39)$ & Mintoum $(n=78)$ \\
\hline \multicolumn{2}{|c|}{ Total Number of Permanent Residents } & 80 & 174 & 437 \\
\hline \multicolumn{2}{|c|}{ Native from the Village } & $56 \%$ & $65 \%$ & $75 \%$ \\
\hline \multirow{2}{*}{ Ethnic Group } & Baka & $0 \%$ & $0 \%$ & $53 \%$ \\
\hline & Bantu & $100 \%$ & $100 \%$ & $47 \%$ \\
\hline \multirow{4}{*}{$\begin{array}{c}\text { Maximum Level } \\
\text { of Education }\end{array}$} & Out-of-school & $0 \%$ & $0 \%$ & $5 \%$ \\
\hline & Primary school & $38 \%$ & $33 \%$ & $46 \%$ \\
\hline & Secondary school & $56 \%$ & $59 \%$ & $47 \%$ \\
\hline & Graduate school & $6 \%$ & $8 \%$ & $2 \%$ \\
\hline \multirow{4}{*}{$\begin{array}{l}\text { Main Source of } \\
\text { Income }\end{array}$} & $\begin{array}{l}\text { Forest-related } \\
\text { activities }\end{array}$ & $73 \%$ & $21 \%$ & $53 \%$ \\
\hline & Agriculture & $7 \%$ & $46 \%$ & $10 \%$ \\
\hline & Salary jobs & $13 \%$ & $10 \%$ & $23 \%$ \\
\hline & Mixed occupation & $7 \%$ & $23 \%$ & $14 \%$ \\
\hline
\end{tabular}

\section{References}

1. Lewis, S.L.; Maslin, M.A. Defining the Anthropocene. Nature 2015, 519, 171-180. [CrossRef]

2. Ceballos, G.; Ehrlich, P.R.; Barnosky, A.D.; García, A.; Pringle, R.M.; Palmer, T.M. Accelerated modern human-induced species losses: Entering the sixth mass extinction. Sci. Adv. 2015, 1, e1400253. [CrossRef] [PubMed] 
3. Millennium Ecosystem Assessment. Ecosystems and Human Well-Being: Synthesis; Island Press: Washington, DC, USA, 2005.

4. Burkhard, B.; de Groot, R.; Costanza, R.; Seppelt, R.; Jørgensen, S.E.; Potschin, M. Solutions for sustaining natural capital and ecosystem services. Ecol. Indic. 2012, 21, 1-6. [CrossRef]

5. de Groot, R.S.; Alkemade, R.; Braat, L.; Hein, L.; Willemen, L. Challenges in integrating the concept of ecosystem services and values in landscape planning, management and decision making. Ecol. Complex. 2010, 7, 260-272. [CrossRef]

6. Fagerholm, N.; Kaeyhko, N.; Ndumbaro, F.; Khamis, M. Community stakeholders' knowledge in landscape assessments- Mapping indicators for landscape services. Ecol. Indic. 2012, 18, 421-433. [CrossRef]

7. Lhoest, S.; Dufrêne, M.; Vermeulen, C.; Oszwald, J.; Doucet, J.-L.; Fayolle, A. Perceptions of ecosystem services provided by tropical forests to local populations in Cameroon. Ecosyst. Serv. 2019, 38, 100956. [CrossRef]

8. The Forests of the Congo Basin-Forests and Climate Change; de Wasseige, C.; Tadoum, M.; Atyi, E.; Doumenge, C. (Eds.) Weyrich SA: Neufchâteau, Belgium, 2015.

9. Abernethy, K.; Maisels, F.; White, L.J.T. Environmental Issues in Central Africa. Annu. Rev. Environ. Resour. 2016, 41, 1-33. [CrossRef]

10. Kleinschroth, F.; Laporte, N.; Laurance, W.F.; Goetz, S.J.; Ghazoul, J. Road expansion and persistence in forests of the Congo Basin. Nat. Sustain. 2019, 2, 628-634. [CrossRef]

11. Achard, F.; Beuchle, R.; Mayaux, P.; Stibig, H.-J.; Bodart, C.; Brink, A.; Carboni, S.; Desclée, B.; Donnay, F.; Eva, H.D.; et al. Determination of tropical deforestation rates and related carbon losses from 1990 to 2010. Glob. Chang. Biol. 2014, 20, 2540-2554. [CrossRef]

12. Igu, N.I.; Marchant, R. Freshwater swamp forest use in the Niger Delta: Perception and insights. J. For. Res. 2017, 22, 44-52. [CrossRef]

13. Egoh, B.N.; O’Farrell, P.J.; Charef, A.; Josephine Gurney, L.; Koellner, T.; Nibam Abi, H.; Egoh, M.; Willemen, L. An African account of ecosystem service provision: Use, threats and policy options for sustainable livelihoods. Ecosyst. Serv. 2012, 2, 71-81. [CrossRef]

14. Ingram, V.; Ndoye, O.; Iponga, D.M.; Tieguhong, J.C.; Nasi, R. Les produits forestiers non ligneux: Contribution aux economies nationales et strategies pour une gestion durable. In Les forêts du bassin du Congo-État des forêts 2010; de Wasseige, C., de Marcken, P., Bayol, N., Hiol Hiol, F., Mayaux, P.H., Desclée, B., Nasi, R., Billand, A., Defourny, P., Eba'a Atyi, R., Eds.; EU publications: Luxembourg, 2012; p. 276. ISBN 978-92-79-22717-2.

15. Fa, J.E.; Peres, C.A.; Meeuwig, J. Bushmeat Exploitation in Tropical Forests: An Intercontinental Comparison. Conserv. Biol. 2002, 16, 232-237. [CrossRef]

16. Nasi, R.; Taber, A.; Van Vliet, N. Empty forests, empty stomachs? Bushmeat and livelihoods in the Congo and Amazon Basins. Int. For. Rev. 2011, 13, 355-368. [CrossRef]

17. Fa, J.E.; Olivero, J.; Real, R.; Farfán, M.A.; Márquez, A.L.; Vargas, J.M.; Ziegler, S.; Wegmann, M.; Brown, D.; Margetts, B.; et al. Disentangling the relative effects of bushmeat availability on human nutrition in central Africa. Sci. Rep. 2015, 5, 8168. [CrossRef]

18. Lescuyer, G.; Nasi, R. Financial and economic values of bushmeat in rural and urban livelihoods in Cameroon: Inputs to the development of public policy. Int. For. Rev. 2016, 18, 93-107. [CrossRef]

19. Sola, P.; Cerutti, P.O.; Zhou, W.; Gautier, D.; Iiyama, M.; Schure, J.; Chenevoy, A.; Yila, J.; Dufe, V.; Nasi, R.; et al. The environmental, socioeconomic, and health impacts of woodfuel value chains in Sub-Saharan Africa: A systematic map. Environ. Evid. 2017, 6, 4. [CrossRef]

20. Eba'a Atyi, R.; Ngouhouo Poufoun, J.; Mvondo Awono, J.-P.; Ngoungoure Manjeli, A.; Sufo Kankeu, R. Economic and social importance of fuelwood in Cameroon. Int. For. Rev. 2016, 18, 52-65. [CrossRef]

21. Sola, P.; Schure, J.; Eba'a Atyi, R.; Gumbo, D.; Okeyo, I. Woodfuel policies and practices in selected countries in Sub-Saharan Africa-A critical review. Bois et Forêts des Tropiques 2019, 340, 5-19.

22. FRMi. FAC-2030-Vision Stratégique et Industrialisation de la Filière Bois en Afrique Centrale-Horizon 2030; Développement intégré et durable de la filière bois dans le Bassin du Congo: Opportunités, défis et recommandations opérationnelles-Plan de travail issu de la mission de cadrage; Rapport Pays Cameroun: Montpellier, France, 2018.

23. Lescuyer, G.; Cerutti, P.O.; Tsanga, R. Contributions of community and individual small-scale logging to sustainable timber management in Cameroon. Int. For. Rev. 2016, 18, 40-51. [CrossRef] 
24. Wangai, P.W.; Burkhard, B.; Müller, F. A review of studies on ecosystem services in Africa. Int. J. Sustain. Built Environ. 2016, 5, 225-245. [CrossRef]

25. Cheng, X.; Van Damme, S.; Li, L.; Uyttenhove, P. Evaluation of cultural ecosystem services: A review of methods. Ecosyst. Serv. 2019, 37, 100925. [CrossRef]

26. Jaligot, R.; Kemajou, A.; Chenal, J. Cultural ecosystem services provision in response to urbanization in Cameroon. Land Use Policy 2018, 79, 641-649. [CrossRef]

27. Plieninger, T.; Bieling, C.; Fagerholm, N.; Byg, A.; Hartel, T.; Hurley, P.; López-Santiago, C.A.; Nagabhatla, N.; Oteros-Rozas, E.; Raymond, C.M.; et al. The role of cultural ecosystem services in landscape management and planning. Curr. Opin. Environ. Sustain. 2015, 14, 28-33. [CrossRef]

28. Raymond, C.M.; Singh, G.G.; Benessaiah, K.; Bernhardt, J.R.; Levine, J.; Nelson, H.; Turner, N.J.; Norton, B.; Tam, J.; Chan, K.M.A. Ecosystem Services and Beyond: Using Multiple Metaphors to Understand Human-Environment Relationships. BioScience 2013, 63, 536-546. [CrossRef]

29. Chan, K.M.A.; Guerry, A.D.; Balvanera, P.; Klain, S.; Satterfield, T.; Basurto, X.; Bostrom, A.; Chuenpagdee, R.; Gould, R.; Halpern, B.S.; et al. Where are Cultural and Social in Ecosystem Services? A Framework for Constructive Engagement. BioScience 2012, 62, 744-756. [CrossRef]

30. Daïnou, K.; Bracke, C.; Vermeulen, C.; Haurez, B.; De Vleeschouwer, J.-Y.; Fayolle, A.; Doucet, J.-L. Hautes Valeurs de Conservation (HVC) dans les Unités Forestières d'Aménagement du Cameroun: Concepts, Choix et Pratiques; Les Presses Agronomiques de Gembloux: Gembloux, Belgium, 2016; ISBN 9782870161463.

31. Jacobs, S.; Dendoncker, N.; Martin-Lopez, B.; Barton, D.N.; Gomez-Baggethun, E.; Boeraeve, F.; McGrath, F.; Vierikko, K.; Geneletti, D.; Katharina, S.J.; et al. A new valuation school: Integrating diverse values of nature in resource and land use decisions. Ecosyst. Serv. 2016, 22, 213-220. [CrossRef]

32. Burkhard, B.; Petrosillo, I.; Costanza, R. Ecosystem services-Bridging ecology, economy and social sciences. Ecol. Complex. 2010, 7, 257-259. [CrossRef]

33. Felipe-Lucia, M.R.; Comín, F.A.; Escalera-Reyes, J. A framework for the social valuation of ecosystem services. AMBIO 2015, 44, 308-318. [CrossRef]

34. Boeraeve, F.; Dendoncker, N.; Jacobs, S.; Gómez-Baggethun, E.-B.; Dufrêne, M. (first) How (not) to perform ecosystem service valuations: Pricing gorillas in the mist. Biodivers. Conserv. 2015, 24, 187-197. [CrossRef]

35. de Groot, R.S.; Wilson, M.A.; Boumans, R.M. A typology for the classification, description and valuation of ecosystem functions, goods and services. Ecol. Econ. 2002, 41, 393-408. [CrossRef]

36. Martín-López, B.; Iniesta-Arandia, I.; García-Llorente, M.; Palomo, I.; Casado-Arzuaga, I.; Amo, D.G.D.; Gómez-Baggethun, E.; Oteros-Rozas, E.; Palacios-Agundez, I.; Willaarts, B.; et al. Uncovering Ecosystem Service Bundles through Social Preferences. PLoS ONE 2012, 7, e38970. [CrossRef]

37. Wilson, M.A.; Carpenter, S.R. Economic Valuation of Freshwater Ecosystem Services in the United States: 1971-1997. Ecol. Appl. 1999, 9, 772.

38. Burkhard, B.; Maes, J. Mapping Ecosystem Services; Pensoft Publishers: Sofia, Bulgaria, 2017.

39. Mengist, W.; Soromessa, T. Assessment of forest ecosystem service research trends and methodological approaches at global level: A meta-analysis. Environ. Syst. Res. 2019, 8, 22. [CrossRef]

40. Ryan, C.M.; Pritchard, R.; McNicol, I.; Owen, M.; Fisher, J.A.; Lehmann, C. Ecosystem services from southern African woodlands and their future under global change. Phil. Trans. R. Soc. B 2016, 371. [CrossRef]

41. Pritchard, R.; Grundy, I.M.; van der Horst, D.; Ryan, C.M. Environmental incomes sustained as provisioning ecosystem service availability declines along a woodland resource gradient in Zimbabwe. World Dev. 2019, 122, 325-338. [CrossRef]

42. Rincón-Ruiz, A.; Arias-Arévalo, P.; Núñez Hernández, J.M.; Cotler, H.; Aguado Caso, M.; Meli, P.; Tauro, A.; Ávila Akerberg, V.D.; Avila-Foucat, V.S.; Cardenas, J.P.; et al. Applying integrated valuation of ecosystem services in Latin America: Insights from 21 case studies. Ecosyst. Serv. 2019, 36, 100901. [CrossRef]

43. Reyes-García, V.; Powell, B.; Díaz-Reviriego, I.; Fernández-Llamazares, Á.; Gallois, S.; Gueze, M. Dietary transitions among three contemporary hunter-gatherers across the tropics. Food Sec. 2019, 11, 109-122. [CrossRef]

44. Gillet, P.; Vermeulen, C.; Doucet, J.-L.; Codina, E.; Lehnebach, C.; Feintrenie, L. What Are the Impacts of Deforestation on the Harvest of Non-Timber Forest Products in Central Africa? Forests 2016, 7, 106. [CrossRef]

45. Wilkie, D.S.; Wieland, M.; Poulsen, J.R. Unsustainable vs. Sustainable Hunting for Food in Gabon: Modeling Short- and Long-Term Gains and Losses. Front. Ecol. Evol. 2019, 7, 357. [CrossRef] 
46. Hartter, J.; Solomon, J.; Ryan, S.J.; Jacobson, S.K.; Goldman, A. Contrasting perceptions of ecosystem services of an African forest park. Environ. Conserv. 2014, 41, 330-340. [CrossRef]

47. Quintas-Soriano, C.; Castro, A.J.; Castro, H.; García-Llorente, M. Impacts of land use change on ecosystem services and implications for human well-being in Spanish drylands. Land Use Policy 2016, 54, 534-548. [CrossRef]

48. Carpenter, S.R.; DeFries, R.; Dietz, T.; Mooney, H.A.; Polasky, S.; Reid, W.V.; Scholes, R.J. Millennium Ecosystem Assessment: Research Needs. Science 2006, 314, 257-258. [CrossRef]

49. Zhang, W.; Kato, E.; Bhandary, P.; Nkonya, E.; Ibrahim, H.I.; Agbonlahor, M.; Ibrahim, H.Y.; Cox, C. Awareness and perceptions of ecosystem services in relation to land use types: Evidence from rural communities in Nigeria. Ecosyst. Serv. 2016, 22, 150-160. [CrossRef]

50. Brondizio, E.S.; Tourneau, F.-M.L. Environmental governance for all. Science 2016, 352, 1272-1273. [CrossRef]

51. Brown, G.; Weber, D. Public Participation GIS: A new method for national park planning. Landsc. Urban Plan. 2011, 102, 1-15. [CrossRef]

52. de Groot, R.S.; Fisher, B.; Christie, M.; Aronson, J.; Braat, L.; Haines-Young, R.; Gowdy, J.; Maltby, E.; Neuville, A.; Polasky, S.; et al. Integrating the ecological and economic dimensions in biodiversity and ecosystem service valuation. In The Economics of Ecosystems and Biodiversity (TEEB): Ecological and Economic Foundations; Earthscan: London, UK; Washington, DC, USA, 2010.

53. Droissart, V.; Dauby, G.; Hardy, O.J.; Deblauwe, V.; Harris, D.J.; Janssens, S.; Mackinder, B.A.; Blach-Overgaard, A.; Sonké, B.; Sosef, M.S.M.; et al. Beyond trees: Biogeographical regionalization of tropical Africa. J. Biogeogr. 2018, 45, 1153-1167. [CrossRef]

54. White, F. The Vegetation of Africa, a Descriptive Memoir to Accompany the UNESCO/AETFAT/UNSO Vegetation Map of Africa; ORSTOM-UNESCO: Paris, France, 1983.

55. Fayolle, A.; Swaine, M.D.; Bastin, J.-F.; Bourland, N.; Comiskey, J.A.; Dauby, G.; Doucet, J.-L.; Gillet, J.-F.; Gourlet-Fleury, S.; Hardy, O.J.; et al. Patterns of tree species composition across tropical African forests. J. Biogeogr. 2014, 41, 2320-2331. [CrossRef]

56. Hijmans, R.J.; Cameron, S.E.; Parra, J.L.; Jones, P.G.; Jarvis, A. Very high resolution interpolated climate surfaces for global land areas. Int. J. Climatol. 2005, 25, 1965-1978. [CrossRef]

57. Cellule Aménagement Pallisco; Nature+. Résumé des plans d'aménagement et des directives FSC pour les UFA 10-030, 10-031, 10-039, 10-041, 10-042 et 10-044 exploitées par la société Pallisco et ses partenaires. 2015. Available online: http://www.pallisco-cifm.com/index.php/fr/amenagement (accessed on 2 September 2019).

58. Vermeulen, C. Le Facteur Humain Dans l'aménagement des Espaces-ressources en Afrique Centrale Forestière: Application aux Badjoué de l'Est Cameroun. Ph.D. Dissertation, Faculté Universitaire des Sciences Agronomiques, Gembloux, Belgium, 2000.

59. Winterbottom, R. Tropical forestry actions plans and indigenous people: The case of Cameroon. In Conservation of West and Central African Rainforest; Cleaver, K., Munasinghe, M., Dyson, N., Egli, A., Peuker, F., Wencelius, F., Eds.; The World Bank Edition: Washington, DC, USA, 1992; pp. 123-125.

60. Guthrie, M. The Classification of the Bantu Languages; Routledge: London, UK, 1948.

61. World Resources Institute. Interactive Forest Atlas of Cameroon: Version 3.0; Overview Report: Washington, DC, USA, 2012; ISBN 978-1-56973-789-7.

62. Forest Stewardship Council. Forest Stewardship Standard for the Republic of Cameroon; FSC International Center GmbH: Bonn, Germany, 2012.

63. Karsenty, A. Certification of tropical forests: A private instrument of public interest? A focus on the Congo Basin. For. Policy Econ. 2019, 106, 101974. [CrossRef]

64. Mayaux, P.; Bartholomé, E.; Fritz, S.; Belward, A. A new land-cover map of Africa for the year 2000. J. Biogeogr. 2004, 31, 861-877. [CrossRef]

65. Collins, D. Pretesting survey instruments: An overview of cognitive methods. Qual. Life Res. 2003, 12, 229-238. [CrossRef] [PubMed]

66. Incomes from the Forest: Methods for the Development and Conservation of Forest Products for Local Communities; Wollenberg, E.; Ingles, A. (Eds.) Center for International Forestry Research: Bogor, Indonesia, 1998; ISBN 979-8764-19-6.

67. Ngabinzeke, J.S.; Masamba, J.B.; M’Vubu, R.N.; Vermeulen, C. Consommation de produits d'origine animale dans la concession forestière 039/11 de la SODEFOR à Oshwe (R.D. Congo). Tropicultura 2014, 32, 147-155. 
68. Rastoin, J.-L.; Ghersi, G. Tendances et déterminants de la consommation alimentaire. In Le Système Alimentaire Mondial: Concepts et Méthodes, Analyses et Dynamiques; Quae: Plouzané, France, 2010.

69. Rist, J.; Milner-Gulland, E.J.; Cowlishaw, G.; Rowcliffe, M. Hunter Reporting of Catch per Unit Effort as a Monitoring Tool in a Bushmeat-Harvesting System. Conserv. Biol. 2010, 24, 489-499. [CrossRef]

70. Hayashi, K. Hunting activities in forest camps among the Baka hunter-gatherers of southeastern Cameroon. Afr. Study Monogr. 2008, 29, 73-92.

71. Fox, J. Firewood consumption in a Nepali village. Environ. Manag. 1984, 8, 243-250. [CrossRef]

72. Fearnside, P.M. Wood density for estimating forest biomass in Brazilian Amazonia. For. Ecol. Manag. 1997, 90, 59-87. [CrossRef]

73. Kalibo, H.W.; Medley, K.E. Participatory resource mapping for adaptive collaborative management at Mt. Kasigau, Kenya. Landsc. Urban Plan. 2007, 82, 145-158. [CrossRef]

74. Larzillière, A.; Vermeulen, C.; Dubiez, E.; Yamba Yamba, T.; Diowo, S.; Mumbere, G. La maquette interactive, un outil novateur de participation. Bois et Forêts des Tropiques 2013, 315, 21-28.

75. Hansen, M.C.; Potapov, P.V.; Moore, R.; Hancher, M.; Turubanova, S.A.; Tyukavina, A.; Thau, D.; Stehman, S.V.; Goetz, S.J.; Loveland, T.R.; et al. High-Resolution Global Maps of 21st-Century Forest Cover Change. Science 2013, 342, 850-853. [CrossRef]

76. Robinson, J.G.; Bennett, E.L. Hunting for Sustainability in Tropical Forests; Columbia University Press: New York, NY, USA, 2000.

77. Djomo, A.N.; Knohl, A.; Gravenhorst, G. Estimations of total ecosystem carbon pools distribution and carbon biomass current annual increment of a moist tropical forest. For. Ecol. Manag. 2011, 261, 1448-1459. [CrossRef]

78. Delvingt, W.; Dethier, M.; Auzel, P.; Jeanmart, P. La chasse villageoise Badjoué, gestion coutumiére durable ou pillage de la ressource gibier?. In La Forêt des Hommes: Terroirs Villageois en Forêt Tropicale Africaine; Les Presses Agronomiques de Gembloux: Gembloux, Belgique, 2001; pp. 65-92.

79. Vermeulen, C.; Karsenty, A. Place et légitimité des terroirs villageois dans la conservation. In La Forêt des Hommes: Terroirs Villageois en Forêt Tropical Africaine; Les Presses Agronomiques de Gembloux: Gembloux, Belgique, 2001; pp. 217-234.

80. Lescuyer, G. Sustainable Forest Management at the Local Scale: A Comparative Analysis of Community Forests and Domestic Forests in Cameroon. Small Scale For. 2013, 12, 51-66. [CrossRef]

81. Auzel, P. Les villes en forêt: Impact de l'exploitation forestière sur la gestion coutumière des ressources naturelles. In La Forêt des Hommes: Terroirs Villageois en Forêt Tropicale Africaine; Les Presses Agronomiques de Gembloux: Gembloux, Belgique, 2001; pp. 235-251.

82. Gillet, P.; Vermeulen, C.; Lehnebach, C.; Codina Llavinia, E. What do humans eat when forests disappear? Nat. Faune 2016, 29.

83. Dethier, M. Analyse de la chasse villageoise en accord avec les superficies accordées par la législation sur les forêts communautaires: Cas du village de Kompia (Périphérie Nord de la réserve de Faune du Dja); Avenir des Peuples des Forêts Tropicales; Faculté des Sciences Agronomiques de Gembloux: Gembloux, Belgique, 1998; p. 13.

84. Willett, W.; Rockström, J.; Loken, B.; Springmann, M.; Lang, T.; Vermeulen, S.; Garnett, T.; Tilman, D.; DeClerck, F.; Wood, A.; et al. Food in the Anthropocene: The EAT-Lancet Commission on healthy diets from sustainable food systems. Lancet 2019, 393, 447-492. [CrossRef]

85. Speedy, A.W. Global Production and Consumption of Animal Source Foods. J. Nutr. 2003, 133, 4048S-4053S. [CrossRef]

86. Reynolds, C.; Buckley, J.; Weinstein, P.; Boland, J. Are the Dietary Guidelines for Meat, Fat, Fruit and Vegetable Consumption Appropriate for Environmental Sustainability? A Review of the Literature. Nutrients 2014, 6, 2251-2265. [CrossRef] [PubMed]

87. Lhoest, S.; Fonteyn, D.; Daïnou, K.; Delbeke, L.; Doucet, J.-L.; Dufrêne, M.; Josso, J.-F.; Ligot, G.; Oszwald, J.; Rivault, E.; et al. Conservation value of tropical forests: Distance to human settlements matters more than management in Central Africa. Biol. Conserv. 2020, 241C, 108351. [CrossRef]

88. Koerner, S.E.; Poulsen, J.R.; Blanchard, E.J.; Okouyi, J.; Clark, C.J. Vertebrate community composition and diversity declines along a defaunation gradient radiating from rural villages in Gabon. J. Appl. Ecol. 2017, 54, 805-814. [CrossRef]

89. Poulsen, J.R.; Clark, C.J.; Bolker, B.M. Decoupling the effects of logging and hunting on an Afrotropical animal community. Ecol. Appl. 2011, 21, 1819-1836. [CrossRef] 
90. Fa, J.E.; Brown, D. Impacts of hunting on mammals in African tropical moist forests: A review and synthesis. Mammal Rev. 2009, 39, 231-264. [CrossRef]

91. Fa, J.E.; Currie, D.; Meeuwig, J. Bushmeat and food security in the Congo Basin: Linkages between wildlife and people's future. Environ. Conserv. 2003, 30, 71-78. [CrossRef]

92. Vermeulen, C.; Julve, C.; Doucet, J.-L.; Monticelli, D. Community hunting in logging concessions: Towards a management model for Cameroon's dense forests. Biodivers. Conserv. 2009, 18, 2705-2718. [CrossRef]

93. Taylor, G.; Scharlemann, J.P.W.; Rowcliffe, M.; Kümpel, N.; Harfoot, M.B.J.; Fa, J.E.; Melisch, R.; Milner-Gulland, E.J.; Bhagwat, S.; Abernethy, K.A.; et al. Synthesising bushmeat research effort in West and Central Africa: A new regional database. Biol. Conserv. 2015, 181, 199-205. [CrossRef]

94. Pesche, D.; Losch, B.; Imbernon, J. Une nouvelle ruralité émergente: Regards croisés sur les transformations rurales africaines; Atlas pour le Programme Rural Futures du NEPAS; Cirad, NEPAD: Montpellier, France, 2016.

95. Charpin, M.; Richter, F. L'énergie Renouvelable-Vers une Modernisation de la Filière Bois-énergie; Vision 2035; Eco-Consulting Group: Oberaula, Germany, 2012.

96. MINFOF. Stratégie de modernisation de la chaine de valeur bois-énergie dans l'Extrême-Nord Cameroun; GIZ: Meroua, Tunisia, 2017.

97. Gazull, L.; Gautier, D. Les grands modes de gestion du bois-énergie. In Mémento du Forestier Tropical; Quae: Versailles, France, 2015; pp. 646-657.

98. de Wachter, P. Économie et impact de l'agriculture itinérante Badjoué [sud-Cameroun]; Civilisations; Université Libre de Bruxelles: Brussels, Belgium, 1997; pp. 62-93.

99. Gallois, S.; Duda, R.; Hewlett, B.; Reyes-García, V. Children's daily activities and knowledge acquisition: A case study among the Baka from southeastern Cameroon. J. Ethnobiol. Ethnomed. 2015, 11, 86. [CrossRef] [PubMed]

100. Oishi, T. Aspects of Interactions between Baka Hunter-Gatherers and Migrant Merchants in Southeastern Cameroon. Senri Ethnol. Stud. 2016, 94, 157-175.

101. Joiris, D.V. La chasse, la chance, le chant: Aspects du système rituel des Baka du Cameroun; Université Libre de Bruxelles: Brussels, Belgiums, 1998.

102. Leclerc, C. L'adoption de l'agriculture chez les Pygmées Baka du Cameroun. Dynamique Sociale et Continuité Structurale; Quae: Versailles, France, 2012.

103. Porro, R.; Tiani, A.M.; Tchikangwa, B.; Sardjono, M.A.; Salim, A.; Colfer, C.J.P.; Brocklesby, M.A. Access to Resources in Forest-Rich and Forest-Poor Contexts. In People Managing Forest: The Links between Human well being and Sustainability; Resources for the Future and CIFOR: Washington, DC, USA, 2001; pp. 250-273.

104. Pröpper, M.; Haupts, F. The culturality of ecosystem services. Emphasizing process and transformation. Ecol. Econ. 2014, 108, 28-35. [CrossRef]

105. Scholte, S.S.K.; van Teeffelen, A.J.A.; Verburg, P.H. Integrating socio-cultural perspectives into ecosystem service valuation: A review of concepts and methods. Ecol. Econ. 2015, 114, 67-78. [CrossRef]

106. Díaz, S.; Pascual, U.; Stenseke, M.; Martín-López, B.; Watson, R.T.; Molnár, Z.; Hill, R.; Chan, K.M.A.; Baste, I.A.; Brauman, K.A.; et al. Assessing nature's contributions to people. Science 2018, 359, $270-272$. [CrossRef]

107. Milcu, A.I.; Hanspach, J.; Abson, D.; Fischer, J. Cultural ecosystem services: A literature review and prospects for future research. Ecol. Soc. 2013, 18, 44. [CrossRef]

108. Pascual, U.; Balvanera, P.; Díaz, S.; Pataki, G.; Roth, E.; Stenseke, M.; Watson, R.T.; Dessane, E.B.; Islar, M.; Kelemen, E.; et al. Valuing nature's contributions to people: The IPBES approach. Curr. Opin. Environ. Sustain. 2017, 26, 7-16. [CrossRef]

(C) 2020 by the authors. Licensee MDPI, Basel, Switzerland. This article is an open access article distributed under the terms and conditions of the Creative Commons Attribution (CC BY) license (http://creativecommons.org/licenses/by/4.0/). 